\title{
Evaluation of Health on a Budget: A Health Promotion Program for Women Experiencing Homelessness
}

by Autumn Hackett

\begin{abstract}
In 2015, the researcher created Health on a Budget, a five-session health promotion class to empower homeless women to live heathier lives on a budget. After enhancing the curriculum using the Theory of Planned Behavior (Ajzen, 1991), the researcher reintroduced the program in 2016 and evaluated its effectiveness. The researcher worked with stakeholders to identify key topics: health literacy in nutrition, portion control, cooking, exercise, and oral and foot hygiene. The researcher created objectives, lesson plans, and evaluation surveys that aligned with the Theory of Planned Behavior. At the conclusion of each session, participants completed a survey that determined the completion of the objectives. Ten women residing at the Center for Transforming Lives shelter in Fort Worth participated in Health on a Budget in 2016. As a whole, the participants met all of the knowledge objectives: $80 \%$ of the attitude objectives, $80 \%$ of the behavioral intention objectives, $40 \%$ of perceived behavioral control objectives, and $20 \%$ of subjective norm objectives. Overall, the program had the greatest effect on the participants' knowledge, attitudes, and intentions to perform healthy behaviors. The program was well-received by the participants, and the shelter stakeholders were very pleased with the program development and outcomes. Although the participants met most of the objectives, it is unclear if the women will take the knowledge they have and use it to change their dayto-day behaviors because of the complexity of their environment and circumstances. Changing shelter policies to improve the food environment and the nutritional content of the food would be more effective in promoting the health behaviors of residents in the short term. In the long term, the provision of stable housing would allow women to begin improving their physical, mental, and emotional health through programs like Health on a Budget.
\end{abstract}

\footnotetext{
${ }^{1}$ I would like thank Dr. Gina Alexander for her thoughtful contributions, constant encouragement, and support throughout the completion of this project. I would also like to thank Dr. J ames Petrovich and Dr. Melissa Sherrod for their input and feedback. I am sincerely thankful for the staff leaders and participants at the YWCA for taking the time to partner with me, welcoming me into their facility with positivity, and providing me with the resources necessary to complete each session. I express my gratitude for Ebony Rose and the Chancellor's Leadership Program for equipping me with lifelong leadership skills and providing funding for the first sessions of Health on a Budget. My sincere thanks to all of the TCU Nursing and TCU Nutrition students who helped me with the initial curriculum and implementation of the program. Lastly, I acknowledge my appreciation for the encouragement and thoughtful words of my peers, close friends, and family throughout this process.
} 


\section{Personal Reflections}

Upon arriving to Texas Christian University (TCU), I heard about the Chancellor's Leadership Program (CLP) and I instantly decided to apply. After filling out the application and participating in an interview, I was selected to join a cohort of 35 students. CLP was designed as a three-and-a-half-year program where a cohort of students meets once a week for lectures, discussions, and activities. The curriculum focuses on ways to utilize one's leadership style and strengths to affect meaningful and intentional social change in the community (TCU Student Development Services, 2015). At the culmination of the program, seniors complete a Legacy Project where they use skills gained through the course of the CLP to implement a project that creates social change. The experience encourages individual growth while also benefitting the surrounding community. As a member of the CLP, I have been challenged and encouraged to develop my self-awareness and leadership skills so that I can create social change in the community around me. I have always been passionate about women's health and serving alongside women in my community. As part of my Social Change Legacy Project, I combined my passion for serving women with my healthcare knowledge to create a health promotion program for women experiencing homelessness.

In 2015 and 2016, I worked with the Young Women's Christian Association (YWCA) of Fort Worth, recently renamed the Center for Transforming Lives. While there, I planned a program that would benefit homeless women who reside in the shelter temporarily and receive skills training while they await transition to more permanent housing. To gain a better perspective of the needs of this population, I 
initiated contact with the volunteer coordinator and case manager at the YWCA. The case manager was able to give me great insight into the general needs of this transient population of women, while the volunteer coordinator was able to give me ideas about what format she thought would best suit the women and their learning styles.

I met with these shelter leaders multiple times prior to the commencement of the program to collaborate and formulate ideas they believed would be most beneficial to the women they serve every day. During these meetings, the volunteer coordinator and case manager highlighted the needs that informed the framework used to develop the Health on a Budget teaching sessions including foot care, oral care, healthy eating, smart grocery shopping, and daily activity. They encouraged me to create lessons that would foster independent skills for a healthy life after the shelter, rather than supplying them with knowledge to make them more dependent on others. Although I did not conduct a needs assessment directly with the women served by the YWCA, the meetings with YWCA staff helped me to see that addressing practical needs through skills-based education would be very useful and align well with the overall mission and vision of the YWCA.

After meeting with shelter leaders, I collaborated with another nursing student to design the curriculum for a program that later became Health on a Budget. The vision of this program is to educate and empower women experiencing homelessness to live healthy lifestyles within their financial means. The most difficult portion of organizing this project was designing curriculum that would fully embrace the vision of this program. We brainstormed with nutrition students who could enhance our nutritionrelated curriculum with their classroom and clinical knowledge. It was relatively easy to combine efforts and create a curriculum based on knowledge and facts; however, it 
proved difficult to make the material relevant and feasible in everyday life for these women. What's more, trying to understand the women's lifestyle and gauge the extent of their autonomy over their life choices made curriculum building even more difficult. Through these challenges, I learned the value of truly understanding a population before trying to intervene and make changes; I needed to realize how these women lived before I could promote behavior change.

After collaborating with YWCA staff and students, we implemented five one-hour sessions of Health on a Budget in J anuary of 2015 as a pilot to test out the curriculum. To evaluate this program, we handed out a brief anonymous survey to participants regarding their experience with Health on a Budget. When reviewing the evaluation survey, we received positive feedback about the overall program and the topics that were most helpful to them. Nearly all of the participants selected the option that Health on a Budget was helpful and that they would like it to continue. Additionally, the YWCA staff repeatedly encouraged the program to continue and requested more sessions of the class.

In the spring of 2015, I took a Research and Theory class where I learned about the Theory of Planned Behavior (Ajzen, 1991). After learning more about the Theory of Planned Behavior (TPB) and reading the evaluations of the pilot program, I decided to integrate TPB into the lesson plans and create objectives and evaluation surveys for each class that aligned with specific TPB constructs. The most rewarding part about editing the curriculum was seeing how it would align with the theory to create a better experience for the participants.

Overall, through my work at the YWCA with the help of the Chancellor's Leadership Program and my classmates, I have experienced personal growth. I have 
learned about another population's way of life and about how their difficulties compare to mine. I have witnessed how dancing has the potential to bring women out of their shells in a matter of minutes. I have conversed with women about their concerns related to faith, health, and life. The most significant way I have grown during this experience is through the understanding that each individual is different and must be treated and advised according to who she is and what she believes. Without a personal approach to care and education, it is difficult to affect change.

\section{Background}

As of 2015, 1,914 homeless individuals lived in Fort Worth, Texas, which is a 33 percent decrease since 2007 (Mayor's Advisory Commission on Homelessness, 2015). Many believe that the decrease in the number of individuals experiencing homelessness is a result of increased community efforts to provide housing for this population. Directions Home, a ten-year plan to eliminate homelessness in Fort Worth, Texas, supports the idea of housing first which prioritizes housing as the primary need of the homeless population. The plan stems from the idea that the first course of action is to give the homeless population permanent housing with access to case managers for stability and consistency before trying to solve any other issues. Once people have housing, they tend to have increased income, greater employment opportunities, mobility, mental and physical health, and life skills (Mayor's Advisory Commission on Homelessness, 2008).

While community efforts in transitional living facilities/ shelters focus on providing basic services to this population, they do not necessarily emphasize health promotion. In one intervention study, a health-focused program aimed to improve homeless women's outcomes in the following areas: housing, substance abuse, mental 
health, employment, child behavioral problems, and interpersonal stress (Slesnick \& Erdem, 2012). Based on conversations with local service providers, these are the standard services provided to homeless individuals. However, once the need for housing is met in the homeless population, health promotion is more plausible, applicable, and effective (Henwood et al., 2013).

The YWCA of Fort Worth provides single women with access to an emergency shelter, permanent supportive housing, rapid re-housing, and shared housing. During their time at the YWCA, the women also have access to counseling, financial empowerment services, and a variety of educational opportunities. Staff members who work directly with the women residents identified the need for health promotion teaching related to oral care, foot care, healthy eating, smarter grocery shopping, and daily activity. With these unmet needs in mind, a five-week health-teaching program called Health on a Budget was initiated. This project will evaluate the effectiveness of Health on a Budget, and the results from this evaluation will be used to improve the program for future sessions.

Plans for the future of this program and its long-term sustainability have been integrated in the framework of Health on a Budget. A consistent relationship exists between the YWCA stakeholders and the Health on a Budget team. The volunteer coordinator at the YWCA printed all of the materials for each class and observed the classes to take notes for further sessions. She had the opportunity to review all of the materials and keep the files for the YWCA's future use. The current team has met with members of TCU's Interprofessional Health Student Organization, TCU Nutrition Club, and TCU nursing students to gain volunteers to continue implementing this program. 
The volunteers have been trained and have observed the past classes. All of the lesson materials have been saved on a file for easy accessibility in the future.

\section{Theoretical Framework}

The Theory of Planned Behavior (TPB), created by Ick Ajzen (1991), indicates that an individual's behavior is influenced by behavioral intentions, attitudes, subjective norms, and perceived behavioral control. Generally, people form attitudes of certain behaviors based on their previous experiences when performing these behaviors. If in the past they experienced positive consequences when performing a behavior, they are more likely to have a positive attitude toward that particular behavior. However, if an individual previously experienced a negative outcome related to a specific behavior he/ she is more likely to have a negative attitude toward that behavior in the future.

Another important aspect of Ajzen's theory is a person's perceived behavioral control in the situation. Perceived behavioral control relates to the level of difficulty a person will encounter when performing a behavior of interest. If a person believes that he/ she can perform a behavior relatively easily and has the means necessary to do so, he/ she is more likely to change that behavior. However, someone who has a perceived lack of control related to a certain behavior, is less likely to perform the behavior (Ajzen, 1991).

The subjective norm refers to an individual's perceived social pressure to perform an action. When an individual feels that his/ her peers are interested in a behavior or perform that behavior, he/ she becomes more aware and accepting of that behavior. Thus, the beliefs, attitudes, and actions of the people in a person's environment will make him/ her more or less likely to partake in that behavior. 
An individual's behavioral intentions refer to the motivational drive and factors that determine a given behavior. The intention to perform a behavior is directly proportional to an individual's likelihood of completing that behavior. Thus, if the motivational factors exist and are favorable, a person has a stronger chance of performing a behavior. The attitudes, subjective norms, and perceived behavioral control all shape an individual's behavioral intention and subsequently his/ her behaviors (Ajzen, 1991).

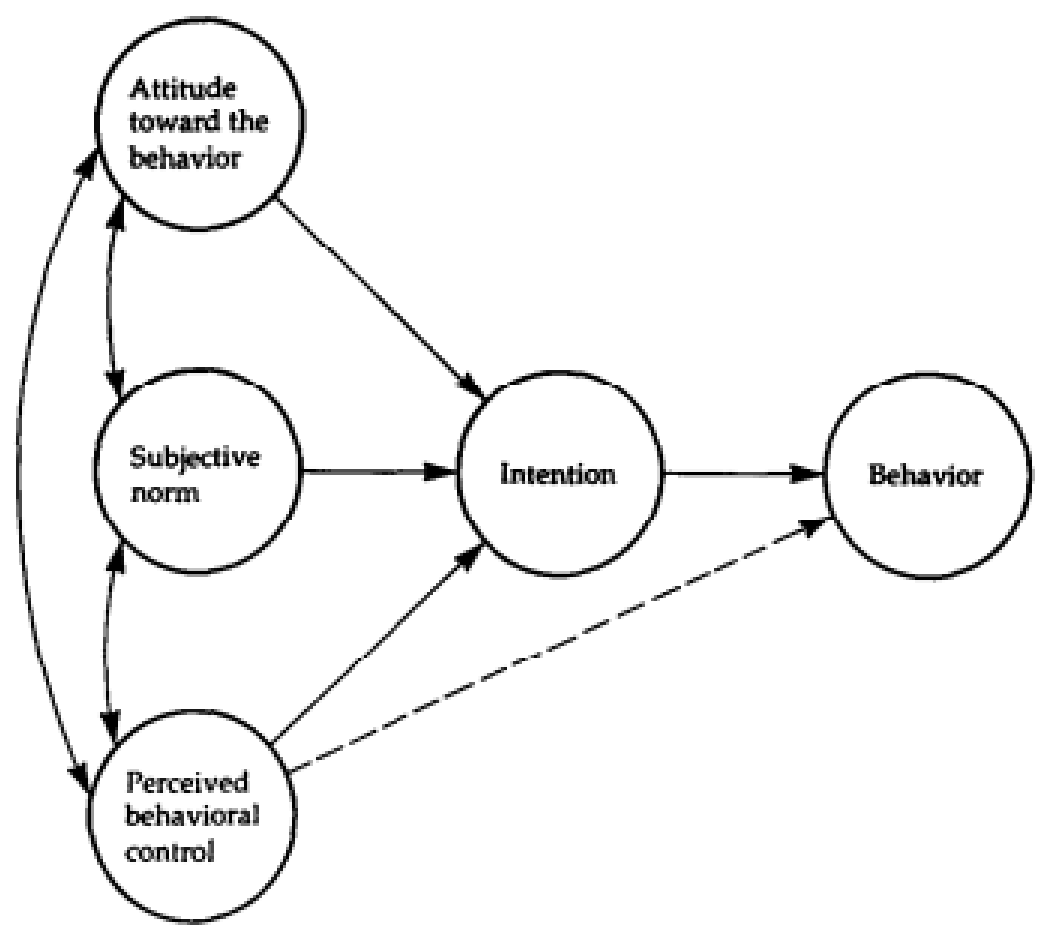

Fig. 1. Theory of planned behavior.

Figure 1 (Ajzen, 1991) depicts how each individual construct of the TPB relates to the behavior in question. It shows how the attitudes, subjective norms, perceived behavioral control, and intentions all affect a behavior.

The Health on a Budget curriculum incorporated strategies that addressed each construct in the TPB. The researcher implemented activities to engage the women in an attempt to influence the subjective norm of the population. The lesson plans included 
discussion about perceived barriers to performing the behaviors to address ways to improve control over the situation. In addition, the researcher addressed the participants' attitudes and intentions to perform the behaviors by allowing the women to discuss specific times and set individual goals to use their knowledge about the topics in the future.

\section{Review of Literature}

Based on the needs identified by YWCA leaders and staff, the following areas were identified as primary education needs for women residing at the shelter: health literacy in nutrition, cooking skills, oral hygiene, foot care, and exercise.

\section{Nutrition Education}

In 1994, the United States Department of Agriculture (USDA) Center for Nutrition Policy and Promotion was created to improve the well-being and nutrition status of Americans. Its goals are to "advance and promote dietary guidance for all Americans and conduct applied research and analyses in nutrition and consumer economics" (USDA, 2015, p. 1). This organization produces graphics and handouts, and provides online tools to educate the public on healthy eating, appropriate weight and calorie consumption, and safe and effective physical activity goals. As a leader in health promotion education, the USDA Center for Nutrition Policy and Promotion created MyPlate and ChooseMyPlate.gov to make their resources easily accessible and understandable. USDA officials and stakeholders created tip sheets focused on saving money at the grocery store and eating healthy on a budget to cater to lower-income individuals and families (USDA, 2015).

A recent study focused on low-income individuals and their food choices (Eikenberry \& Smith, 2004). When low-income individuals were asked about their idea 
of healthy eating, the most common examples they gave were fruits and vegetables. The same individuals indicated that their main motivations, or behavioral intentions, to eat healthy were related to their health, weight, and concerns regarding their families. Knowing that the participants' behavioral intention related to these factors, the intervention design included information of the effects that eating healthy has on the women's health, weight, and families. In addition, almost half of the 796 participants listed time and more than one-third identified money concerns as barriers to healthy eating (Eikenberry \& Smith, 2004). Due to limited income and high prices of perceived healthy foods, many women experience a disconnect between what they know is healthy and what they can afford to feed themselves and their families. This evidence highlights the need for increased interventions to educate individuals with lower incomes on relatively inexpensive, yet healthy, eating (Dammann \& Smith, 2009).

While investigating a short-term interventional program focused on nutrition, Rustad and Smith (2013) found that women with limited income were able to improve their nutritional knowledge and increase healthy eating and shopping behaviors. Thus, when implementing health-promotion classes, it is important to include effective ways to eat healthier on a budget without adding significant time to food preparation. Addressing the concern of money and time were purposeful strategies to increase the participant's perceived behavioral control by giving them confidence and strategies to gain more control over the factors that they may have felt were once out of their control.

\section{Cooking Skills}

With the rise of low-cost pre-prepared food items, many people have begun to move away from preparing foods at home. Black et al. (2004) evaluated the effect of providing a recipe booklet for use by women on the Special Supplemental Nutrition 
Program for Women, Infants and Children (WIC). Researchers found that after receiving the booklet, $70 \%$ of women reported feeling more confident about choosing produce and $74 \%$ of women felt that it was easier to use fruits and vegetables in daily cooking (Black, et al., 2004). Research indicates that providing individuals with handson experience may improve their likelihood of long-term dietary success.

Another method for improving outcomes among women with limited income is to work closely with the community and key stakeholders to gain better perspective on the needs of the population (Davies, Damani, \& Margetts, 2009). The more the curriculum and teaching applies to a specific population, the better the participants react to the educational materials. The USDA Center for Nutrition Policy and Promotion provides recipes and cookbooks on its website to promote healthy at-home meals. In addition, the USDA maintains an interactive tool online to help simulate healthy meal planning and cooking. This format allows individuals to feel more control over what they eat and can offer new ideas of what it looks like to cook and eat healthy foods (USDA, 2015). The cookbook tool even lists price per serving, for those who are mindful of their budget, and the nutrition facts for individuals who like to record their intake.

\section{Oral Care}

Access to dental care is limited for the general population and can be extremely difficult for limited-income individuals. There is often a divide between private dental practice, fee-for-service payment locations, and the oral health needs of low-income individuals (Wallace \& MacEntee, 2012). Dental hygiene is perceived as a low priority among low-income individuals due to the financial barriers that come with receiving dental care (Muirhead, Quiñonez, Figueriredo \& Locker, 2009). 
Individuals who do not have a positive attitude toward dental care will subsequently have a decreased likelihood of seeking access to dental care. In addition, those who feel that cost is the main barrier to receiving care have less perceived behavioral control. Perceiving dental care as a low priority and having low perceived behavioral control of oral care decrease the likelihood that low-income individuals will receive preventive oral care. Evidence suggests that increasing access and availability of dental clinics trained to assist low-income individuals may have beneficial effects in better serving this population (Wallace \& MacEntee, 2012). Interventions aimed at improving attitudes toward seeking preventive care and connecting individuals with local services aimed at providing dental care for low-income individuals may contribute to improved oral health.

In addition to the need for specialty dental clinics to serve the homeless population, it is important to consider the need for communication and education regarding daily self-care behaviors to promote oral hygiene. The American Dental Association (ADA) has worked diligently over the last ten years to provide simple oral health resources to community members who may have lower health literacy (Association of State and Territorial Dental Directors, 2008). A public program titled MouthHealthy with web access launched in J une of 2012 to provide resources for the public to learn about dental symptoms, oral care at different stages in their life, and to discuss nutritional hints for a healthier mouth. MouthHealthy also displays proper brushing technique in a variety of written materials and videos (ADA, 2014).

In addition to these resources provided by the ADA the Centers for Disease Control (CDC) emphasizes the need to address risk factors for oral cancer; in particular, recent research attributes oral cancer to tobacco and excessive alcohol use in up to 75 
percent of cases (CDC, 2011). Around 75 percent of the homeless population smoke cigarettes, which is four times that in the United States general population (Baggett, Tobey \& Rigotti, 2013). Moreover, 34.7 percent of adults in homeless shelters experienced chronic substance abuse (US Department of Housing and Urban Development, 2011). The alcohol abuse and smoking habits in this population lead to a disproportionately high number of deaths due to socioeconomic disparities in access to healthcare. Thus, it is critical to remind this population of the oral cancer risks associated with tobacco and excessive alcohol intake.

\section{Foot Care}

Few research studies have examined the specific foot care needs of the homeless; more research in this specific area is needed to inform practice. Poor foot care is a major health concern and homeless individuals have more risk factors for poor foot health than the general population (Chen, Mitchell, \&Tran, 2012). Women experiencing homelessness tend to spend long periods of time walking and standing which leads to venous stasis, edema, and cellulitis. In addition, they are more susceptible to poor foot hygiene, unsanitary living conditions, and ill-fitting shoes, all of which predispose them to abrasions, infections, abscesses, corns, and calluses (Maness \& Khan, 2014). These problems tend to result in less injury when prevented and recognized early. Thus, education regarding early detection of abnormalities, management of environmental conditions, and proper fitting shoes may help to prevent complications.

\section{Physical Activity}

Individuals living in poverty and those with a lower socioeconomic background tend to have less health consciousness, stronger beliefs in chance to determine health, less futuristic thinking, and lower life expectancies. In addition, they often have 
different beliefs and attitudes about a variety of health factors, including leisure time physical activity (Wardle \& Steptoe, 2002). According to the TPB, an important step in creating behavioral change is attempting to modify a person's attitudes and beliefs (Ajzen, 1991).

Economically disadvantaged individuals often report cost, time, and lack of childcare as obstacles to participating in physical exercise or activity on a regular basis. Strategies to improve participation of low-income populations in physical activity are focused on fun and socializing, low cost, and a low time commitment (Withall, J ago, \& Fox). Fostering an environment where the subjective norm is for women to feel supported, have friends performing activities beside them, and where physical activity is portrayed positively may improve the women's' attitudes and intentions to exercise (Speck, Hines-Martin, Stetson, \& Looney, 2007).

\section{Methods}

\section{Sampling Procedures}

The sample consisted of all of the residents receiving services at the YWCA in J anuary and February of 2016. To participate in the project, participants must have provided informed consent, read the anonymous survey at the end of each lesson, and must have attended the class being evaluated. The YWCA encouraged all eligible women to participate in weekly classes while residing there.

\section{Institutional Review Board Approval}

The investigator obtained approval from the TCU Institutional Review Board (IRB) in September of 2015. 


\section{Program Description}

Each of the Health on a Budget topics has a distinct lesson plan with clear objectives to be achieved by the end of that session (See Appendix A). In addition to the lesson plans, each topic has an evaluation survey to evaluate the completion of the objectives at the end of each session (See Appendix B). The objectives, lesson plans, and evaluation surveys align with the health-promotion needs of low-income or homeless individuals discussed in current literature and with the YWCA stakeholders. During each session, participants received handouts that align with current literature aimed at low-income individuals and people with low health-literacy levels (See Appendix C).

In addition, each objective, lesson plan, and evaluation tool matched with a construct from the Theory of Planned Behavior; that is, behavioral intention, social norm, attitude, perceived behavioral control (Ajzen, 1991). Ajzen's writing about effective measures to evaluate these constructs guided the development of the study's materials.

\section{Health Literacy in Nutrition}

During the Nutrition Labels session, the instructors discussed the importance and skills involved in reading a nutrition label. The objectives for the class were as follows: (1) identify the nutrient content of foods by reading the nutrition label; (2) calculate the calorie content in a unit of food and compare it with the calorie content of one serving size; (3) express the value and importance of reading nutrition labels; (4) partner with a friend to read a nutrition label; (5) describe situations in which they will read nutrition labels; (6) express confidence in their ability to read nutrition labels. Initially, participants worked individually to complete a pretest to assess their health literacy in regard to food labels. Next, the instructors used a sample nutrition label and 
outlined the steps in which to begin comprehending the label. Later, the women worked in pairs to read and analyze the different sections of the label and complete a post assessment to test their knowledge. They all collaborated to formulate six reasons why it is important to read nutrition labels and wrote two feasible scenarios in which they could read a nutrition label. At the end of the session, the women completed an anonymous evaluation survey which individually addressed each objective listed in the lesson plan.

\section{Portions and Easy Food Swaps}

During this session, the instructors taught participants about meal portion sizes, proportions, and practical food swaps to eat and live healthier. The objectives of the session were as follows: (1) list two easy food swaps that they plan to make to create a healthier meal; (2) work in groups to color and correctly fill out a well-proportioned plate; (3) express confidence in their ability to plan a healthy meal; (4) express the value and importance of controlling portion size and choosing healthier foods; (5) share a healthy eating tip with another member of the class. First, the instructors explained the difference between energy dense and non-energy dense foods. Then, they listed ideas for food swaps to switch out unhealthy foods with healthier choices. The participants then wrote two of their own food swap ideas or two swaps listed in the examples that they would like to try out. After explaining the MyPlate sample plate builder tool, the instructors passed out the 10 Tips to Eating Better on a Budget and the 10 Tips to Planning Better Meals handouts for their future reference. Next, the women received paper plates and markers to work in groups to color a plate to match the MyPlate portion recommendations (See Appendix C). After completion of this activity, the instructors gave the participants a sample meal plan for a day that contained reasonably 
low cost portions and ingredients. At the end of the session, the women completed an anonymous evaluation survey that individually assessed the objectives listed in the lesson plan.

\section{Cooking Skills}

The Cooking on a Budget lesson aimed to teach residents the skills and knowledge to cook healthy meals at their current and future place of residence. The objectives of the cooking class were as follows: (1) express the value and importance of cooking at home recipes; (2) participate in preparation of the meal alongside peers; (3) plan to prepare a meal using the resources from the lesson in the next month; (4) express confidence in their ability to read nutrition labels. The class began with a variety of money and timesaving tips to aid in preparing meals. Next, volunteers passed out printed recipe ideas

for at-ease meal preparation. The recipes were retrieved from a document titled Good and Cheap which compiles recipes that cost very little (Brown, 2014). Next, the nutrition students assigned chopping and measuring tasks to each participant while explaining the proper technique for each task. While the meal cooked, the instructors asked the women about ways in which they could cook healthier and more efficiently. When the recipe was finished, the women ate and developed rapport with each other and the instructors. The participants then completed an evaluation survey created according to TPB that evaluated each objective.

\section{Oral and Foot Care}

The Oral Hygiene and Foot Care class emphasized the importance of taking good care of these fragile areas of the body. The objectives for the class are as follows: (1) list three ways that they can improve their mouth or foot health; (2) express the value and importance of maintaining healthy teeth and feet; (3) demonstrate correct foot care 
maintenance alongside their peers; (4) articulate intention to make an appointment with their dentist or dental clinic in the next six months; (5) express confidence in their ability to perform oral and foot care. The class began with handing out information sheets with tips and facts about proper oral and foot hygiene (See Appendix C). The materials focused on practical ways to better manage self-care related to oral and foot hygiene. Next, the instructors discussed in depth the proper technique for brushing and flossing and then examined the consequences of poor oral hygiene. The women then received information about tobacco use and diabetes being risk factors for poor oral hygiene and received a handout of local clinics in the area that perform routine dental cleanings (See Appendix C).

Proper daily and weekly foot care was discussed, as well as tips to maintain healthy feet. The women then had the opportunity to practice proper foot hygiene and converse with one another while performing these behaviors. Lastly, the participants completed an evaluation survey to evaluate the selected objectives for this class (See Appendix B).

\section{Exercise}

The Exercise for the Mind, Body, and Soul session addressed the benefits of regular exercise and methods for increasing physical activity on a daily basis. The objectives for the lesson are as follows: (1) express the value and importance of regular exercise as it relates to overall health; (2) share exercise goals with other peers, and participate in an instructed exercise course; (3) create exercise goals for themselves for the next month; (4) express confidence in their ability to incorporate exercise into their weekly routine. The class began by stressing how physical activity or exercise contributes to the health of one's mind, body, and soul. Next, the instructors demonstrated exercises and stretches that the women could complete without 
equipment. The women then received goal sheets that they used to set exercise goals for themselves for the next month. Finally, a TCU nursing student lead a 20-minute yoga class where women could choose to follow along with the instructor. At the end, the women completed an evaluation survey that addressed each objective for the class.

\section{Data Analysis}

The investigator used descriptive statistics to describe the sample based on analysis of demographic data (See Appendix D1). The evaluation surveys completed at the end of each session were the main focus of data analysis. The analysis determined the extent to which the objectives for each session were achieved. At the end of each lesson plan is a description of the strategies used for the evaluation of objectives (See Appendix A).

\section{Results}

The results from this study describe the degree to which the participants met objectives for each session. Within each session, the researcher designed objectives based on the Theory of Planned Behavior and evaluated them accordingly (Ajzen, 1991).

\section{Sample Description}

The researcher collected demographic data from six participants in the program on the first session date. Four additional women participated in the classes but did not provide demographic data. The following data represent the six women with complete demographic data (See Appendix D1). Participants ranged in age from 26 to 69 years old with a mean age of 51.8 ( \pm 14.33$)$. Half of participants identified themselves as African American. Sixty-six percent reported graduating from high school or receiving their GED as their highest form of education. In addition, half of the women identified as single or never married. The length of time the participants claimed they had lived in the 
shelter ranged from one day to one year. The largest percentage of women resided in the shelter between five and eight months. Among the six women who reported demographic information, three (50\%) selected that they were not employed but were looking for a job and three (50\%) reported that they were disabled and unable to work.

Table D1

Sample Description Characteristics*

\begin{tabular}{|l|l|}
\hline Characteristic & Number \\
\hline Age & $51.8(14.33)$ \\
\hline $\begin{array}{c}\text { Mean (standard } \\
\text { deviation) }\end{array}$ & $26-69$ \\
\hline Range & $3(50 \%)$ \\
\hline Ethnicity & $2(33.3 \%)$ \\
\hline African American & $1(16.7 \%)$ \\
\hline Caucasian & \\
\hline Hispanic/ Latino & $4(66.7 \%)$ \\
\hline Highest Level of Education & \\
\hline $\begin{array}{c}\text { High School graduate/ } \\
\text { GED }\end{array}$ & $1(16.7 \%)$ \\
\hline Some College & $1(16.7 \%)$ \\
\hline Bachelor's Degree & $3(50 \%)$ \\
\hline Marital Status & $2(33.3 \%)$ \\
\hline Single, Never Married & $1(16.7 \%)$ \\
\hline Divorced & \\
\hline Widowed & $1(16.7 \%)$ \\
\hline Length of time in Shelter & $1(16.7 \%)$ \\
\hline$<1$ week & $1(16.7 \%)$ \\
\hline 1 week- 1 month & $2(33.3 \%)$ \\
\hline 1-4 months & $1(16.7 \%)$ \\
\hline 5-8 months & \\
\hline 9-12 months & $3(50 \%)$ \\
\hline Employment Status & $3(50 \%)$ \\
\hline $\begin{array}{c}\text { Not employed, looking for } \\
\text { job }\end{array}$ & \\
\hline Disabled, not able to work & \\
\hline
\end{tabular}

*Demographic data not gathered on 4 additional participants 


\section{Health Literacy in Nutrition}

The health literacy and nutrition education lesson had specific teaching interventions to address each TPB objective. As seen in Table E1, of the five objectives designed for this class, one was met, two were partially met, and two were unmet. By the end of the session, participants knew how to read nutrition labels. They participated in partner activities but did not believe that their social contacts valued the practice of choosing foods based on nutrient content. In addition, some struggled with the likelihood of applying this knowledge in their daily lives. Overall, the women did not identify the link between reading nutrition labels and choosing healthier foods and did not express the intent to read nutrition labels regularly.

\section{Portions and Easy Food Swaps}

The portion control and easy food swap session evaluation tool revealed that four of five objectives were met with only one objective partially met. Participants were able to use MyPlate to design healthy meals, including food swaps to exchange unhealthy items for healthy ones. Furthermore, they intended to use this strategy in the future. However, some participants expressed that their social contacts do not value the skill of building and eating healthy meals.

\section{Cooking Skills}

During the cooking skills session, four of five objectives were met and one objective was partially met. Overall, the women agreed that better knowledge about grocery shopping can help to improve the amount of healthy food that they consume and that it is important to plan and cook healthy meals. They also expressed the intention to prepare their meals in a safer manner and use the skills addressed within the session. In contrast, the women did not express that they perceived control over the 
types of food that they cook and eat. While they acknowledged that they felt confident in their ability to plan a healthy meal, they did not feel that their food selection was completely within their control.

\section{Oral and Foot Care}

Out of five objectives related to oral and foot care, three were met, one was partially met, and one was unmet. All of the women recognized the importance of practicing regular oral and foot hygiene. They expressed the intention to visit a dental clinic or office and to refer to the foot care handout provided. However, while the participants felt confident in their ability for oral hygiene, they did not indicate feeling in control of their daily hygiene behaviors. Furthermore, few women participated in the foot care activity at the end of the session.

\section{Exercise}

Participants in the exercise session met three objectives and partially met the other objective. All of the women believed that exercise improves their health and expressed the intention to increase the amount that they exercise on a weekly basis by creating goals for themselves. In addition, the participants noted that their social contacts want them to participate in exercise even though they do not participate in exercise of their own.

\section{Overall Objective Analysis}

The participants in the exercise met all of the knowledge objectives, which indicates that there was either no prior gap in knowledge on health promotion topics or the program was effective in providing the women with information that they can understand and can actively recall (See Table E2). Overall, participants met $80 \%$ of the attitude objectives, which indicates that the participants saw the value of the knowledge 
and that it was important for their health. In addition, participants met $80 \%$ of the behavioral intention objectives, which means that most of them intended to apply the knowledge to their lives. In contrast, fewer women were able to meet objectives related to perceived behavioral control and subjective norm. Some did not think that the behavior was under their control, nor did they perceive social support for the behavior from their close contacts.

Table E1

Class Objective Completion

\begin{tabular}{|l|l|l|l|l|l|}
\hline & \multicolumn{5}{|c|}{ Construct from the Theory of Planned Behavior } \\
\hline Session Title & Attitude & $\begin{array}{l}\text { Subjective } \\
\text { Norm }\end{array}$ & $\begin{array}{l}\text { Behavioral } \\
\text { Intention }\end{array}$ & $\begin{array}{l}\text { Perceived } \\
\text { Behavioral } \\
\text { Control }\end{array}$ & Knowledge \\
\hline $\begin{array}{l}\text { Health } \\
\text { Literacy }\end{array}$ & Unmet & $\begin{array}{l}\text { Partially } \\
\text { Met }\end{array}$ & Unmet & $\begin{array}{l}\text { Partially } \\
\text { Met }\end{array}$ & Met \\
\hline $\begin{array}{l}\text { Portion } \\
\text { Control and } \\
\text { Easy Food } \\
\text { Swaps }\end{array}$ & Met & $\begin{array}{l}\text { Partially } \\
\text { Met }\end{array}$ & Met & Met & Met \\
\hline $\begin{array}{l}\text { Cooking Skills } \\
\text { Oral and Foot }\end{array}$ & Met & Met & Met & $\begin{array}{l}\text { Partially } \\
\text { Met }\end{array}$ & \\
\hline Care & Met & $\begin{array}{l}\text { Partially } \\
\text { Met }\end{array}$ & Met & $\begin{array}{l}\text { Partially } \\
\text { Met }\end{array}$ & Met \\
\hline Exercise & & & & & \\
\hline
\end{tabular}

Table E2

TPB Objective Completion

\begin{tabular}{|l|l|l|l|}
\hline & \multicolumn{3}{|c|}{ Evaluation of Session Objectives } \\
\hline TPB Construct & Met & Unmet & Partially Met \\
\hline Attitude & $80 \%(4 / 5$ & $20 \%(1 / 5$ & $0 \%(0 / 5$ \\
& Sessions) & Sessions) & Sessions) \\
\hline Subjective Norm & $20 \%(1 / 5$ & $20 \%(1 / 5$ & $60 \%(3 / 5$ \\
& Sessions) & Sessions) & Sessions \\
\hline
\end{tabular}




\begin{tabular}{|l|l|l|l|}
\hline $\begin{array}{l}\text { Behavioral } \\
\text { Intention }\end{array}$ & $\begin{array}{l}80 \%(4 / 5 \\
\text { Sessions) }\end{array}$ & $\begin{array}{l}20 \%(1 / 5 \\
\text { Sessions })\end{array}$ & $\begin{array}{l}0 \%(0 / 5 \\
\text { Sessions })\end{array}$ \\
\hline $\begin{array}{l}\text { Perceived } \\
\text { Behavioral } \\
\text { Control }\end{array}$ & $\begin{array}{l}40 \%(2 / 5 \\
\text { Sessions })\end{array}$ & $\begin{array}{l}0 \%(0 / 5 \\
\text { Sessions })\end{array}$ & $\begin{array}{l}60 \%(3 / 5 \\
\text { Sessions })\end{array}$ \\
\hline Knowledge & $\begin{array}{l}100 \%(3 / 3 \\
\text { Sessions })\end{array}$ & $\begin{array}{l}0 \%(0 / 3 \\
\text { Sessions })\end{array}$ & $\begin{array}{l}0 \%(0 / 3 \\
\text { Sessions })\end{array}$ \\
\hline
\end{tabular}

\section{Discussion}

The purpose of this study was to evaluate the effectiveness of Health on a Budget. Overall, survey responses indicated that the women grasped session-specific knowledge, valued healthy behaviors, and intended to improve their health. However, it is unclear if the women will take the knowledge they have and use it to change their day-to-day behaviors because of the complexity of their environment and circumstances. Two recent studies evaluating nutrition education came to the same conclusion. Researchers found that nutrition classes improved knowledge among participants; however, the food services provided in the shelter and other environmental factors impeded the participants' ability to practice healthier eating behaviors (Rodriguez , Applebaum, Stephenson-Hunter, Tinio, \&Shapiro, 2013; Yousey, Leake, Wdowik, \&J anken, 2007). The environment at the shelter may also influence women's perceptions that they did not have as much control over the decisions they make regarding their health. Perhaps changing shelter policies to improve the food environment and the nutritional content of food may be more effective in promoting health behaviors of residents.

The Health on a Budget program did not effectively change the way that women perceived their peer support in practicing healthier behaviors. While the instructors 
encouraged active participation in the sessions to foster social support and connection, the program design did not take into account the nature of the relationships residents had with one another. All of the women in the class resided in the shelter; however, some of them had recently arrived and had not had a chance to bond with others. Moreover, Hayward et al. (2015) found that some residents experience a lack of trust with their neighbors in public housing communities which results in a lack of social support and connectedness. Perhaps the women did not have enough time to form trusting relationships with one another, but there is also the chance that they may not have the desire to build friendships with one another, given the transient nature of shelter living. The program could be more effective if it targeted the close companions of the participants rather than the individuals with whom they reside at the shelter.

\section{Study Limitations}

While reflecting on the implications of the results, the researcher recognizes the limitations of this study. Due to concerns about burdening participants in a vulnerable population, the researcher chose not to administer pre-tests, but the lack of a pre-test to determine prior knowledge and attitudes toward healthy behaviors is one limitation of the study. Another limitation is the lack of demographic data for some of the participants. In addition, relying solely on surveys at the end of each session increases the likelihood of a self-report bias.

Perhaps the most significant limitations of the study are the small sample size and the brevity of the intervention. J ust before implementation of the classes, the shelter underwent construction and renovation that required residents to move to a different location offsite, which led to fewer participants in the study. Also, the program 
included five one-hour sessions which may not have provided enough time for the researcher to influence the long-term behavior of women.

\section{Lessons Learned}

Through the process of planning and implementing this program, a few noteworthy lessons were learned. First, it is very difficult to meet the needs of an everchanging population at an emergency shelter. The diversity in background and knowledge base helps in facilitating discussion among participants, but also presents a challenge in creating curriculum that is helpful for everyone. In addition, effectively changing behavior among women in a vulnerable population proves difficult because of the complex circumstances faced by each individual.

Planning curriculum and developing community partners requires effective communication and planning skills. This program is the result of 16 months of partnership and collaboration, all of which would not be possible without persistence and commitment. It is necessary to have community partners who share in the program's mission in order to create a sustainable program. Involving as many stakeholders as possible is a strategy to extend the quality and sustainability of any effort toward behavior change among vulnerable populations.

\section{Implications for Practice}

Public health officials must advocate for stable housing for women and individuals experiencing homelessness in order to create a physical and social environment where these individuals may thrive and healthy behaviors become integrated in the culture (American Nurses Association, 2013). Currently, the Fort Worth community has Directions Home, a plan to end chronic homelessness using the "Housing First" approach. This approach is to increase permanent supportive housing, 
provide accountability for participants, and prevent future homelessness in the community (Mayor's Advisory Commission on Homelessness, 2015).

Providing stable housing would allow women to begin improving their physical, mental, and emotional health through programs like Health on a Budget. FitzpatrickLewis et al. (2011) found that improving access to housing that requires abstinence from substances and access to case management services helps women become long-term participants in community-based programs. In addition, it is important for community shelters to encourage and promote healthy behaviors through educational classes and policies that provide resources, like healthier foods, aligning with the health education classes. Health promotion classes may be able to impact the behavior of women in Fort Worth if the shelters provide the support the women need in maintaining these behaviors.

\section{Implications for Research}

Further research is necessary to identify whether any health promotion program has long-term effects on the attitudes, intentions, and behaviors of low-income or homeless women. Studies designed to change behavior should include strategies for longitudinal data collection to evaluate behaviors over time and to assess the desired health topics the women would like covered in future sessions. In addition, additional research could determine more effective ways of implementing health promotion programs in a vulnerable community. Perhaps implementing Health on a Budget after achieving stable housing for participants would improve behavioral control for participants and make the program more effective. 


\section{Personal Reflections}

Health on a Budget was grounded in theory and incorporated curriculum specifically designed to align with key TPB constructs. The program provided knowledge, stressed the importance of healthy behaviors to improve participants' attitudes and intentions, and encouraged activities to allow women to see that their peers also had an interest in living healthier lifestyles. Implementation of Health on a Budget demonstrates the feasibility of preparing and implementing health promotion curriculum at a homeless shelter. Developments following completion of the program indicate the potential for sustainability. In particular, the shelter stakeholders requested staff training to continue Health on a Budget annually. Shelter personnel came to this decision because participants continued to attend the program over the course of five sessions and consistently affirmed the desire to learn about each topic included in the curriculum. In addition, they expressed an interest in attending future sessions of Health on a Budget. Despite challenges in the implementation of Health on a Budget, the implementation occurred as envisioned and hopefully will continue to be a beneficial resource to YWCA stakeholders and residents.

\section{Concluding Remarks}

The Chancellor's Leadership Program Social Legacy Project served to teach me the skills necessary to create lasting change in the community while also enhancing my own leadership abilities and problem-solving skills. CLP helped me understand the necessity of collaborating with stakeholders to find a common purpose and committing to a single vision. The process of planning, implementing, revising, and evaluating Health on a Budget has been just as rewarding as it was challenging. Through the completion of this project, the Health on a Budget curriculum has morphed from simply 
ideas, into a theory-based health education program. However, CLP is not the only organization that prepared me to complete this program. The Harris College of Nursing and Health Sciences expanded my horizons to consider the broad determinants of health. Illness and disease are traced back to socioeconomic and physical barriers to practicing healthy behaviors; if these areas are not addressed, we cannot prevent the illnesses and circumstances that are all too common in our community and the world. The J ohn V. Roach Honors College led me to investigate not only the problems faced by my own social network, but those of the greater community. I hope that in the future, I can continue to explore the experience of homelessness and solutions that can provide a better life for the hundreds of thousands of homeless individuals in our nation alone. While this project influenced a small community of women experiencing homelessness in Fort Worth, I have gained the knowledge, skills, and passion to continue pursuing projects to fulfill TCU's mission of creating "ethical leaders and responsible citizens in the global community." 


\section{References}

Ajzen, I. (1991). "The Theory of Planned Behavior." Organizational Behavior and Human Decision Processes, 50(2), 179-211. doi:10.1016/ 0749-5978(91)90020-T

American Dental Association. (2014). Mouth healthy. Retrieved from http:/ / www.mouthhealthy.org/ en/

American Nurses Association. (2013). Public health nursing: Scope and standards of practice. Silver Spring, MD: American Nurses Publishing.

Association of State and Territorial Dental Directors. (2008). Best practice approaches for state and community oral health programs. Retrieved from http:/ / www.astdd.org/ bestpractices-bpastatecoalitions.pdf

Baggett, T., Tobey, M., \& Rigotti, A. (2013). Tobacco use among homeless peopleaddressing the neglected addiction. New England J ournal of Medicine, 369(3), 201-204. doi: 10.1056/NEJ Mp1301935

Black, M. M., Cutts, D. B., Frank, D. A., Geppert, J ., Skalicky, A., Levenson, S., \& Herren, T. (2004). "Special supplemental nutrition program for women, infants, and children participation and infants' growth and health: A multisite surveillance study.” Pediatrics, 114(1), 169-176. Retrieved from http:// www.ncbi.nlm.nih.gov/ pubmed/ 15231924

Brown, L. (2014). Good and cheap: Eat well on \$4/ day (1st ed., Vol. 1, pp. 1-2). New York, NY: Workman Publishing.

Centers for Disease Control and Prevention. (2011). Oral health program strategic plan 2011-2014. Retrieved from http:// www.cdc.gov/ oralhealth/pdfs/oral_health_strategic_plan.pdf 
Chen, B., Mitchell, A., \&Tran, D. (2012). Podiatric health needs of homeless populations as a public health concern. J ournal of The American Podiatric Medical Association, 102(1), 54-56. Retrieved from http:// tci.ncl.edu.tw/ cgibin/gs32/ gsweb.cgi?o=dnclresource\&s=id=\%22A12033895\%22.\&searchmode=b asic\&tcihsspage=tcisearch_opt1_search

Dammann, W., \& Smith, C. (2009). Factors affecting low-income women's food choices and the perceived impact of dietary intake and socioeconomic status on their health and weight. J ournal of Nutrition Education and Behavior, 41, 242-253 . doi: 10.1016/j.jneb.2008.07.003

Davies, J . A., Damani, P., \& Margetts, B. M. (2009). Intervening to change the diets of low-income women. The Proceedings of the Nutrition Society, 68(2), 210-5. doi:http:// dx.doi.org/ 10.1017/S0029665109001128

DeJ esus M., Puleo E., Shelton R., \&Emmons K. (2010). Associations between perceived social environment and neighborhood safety: health implications. Health Place.16:1007- 13. doi:10.1016/j.healthplace.2010.06.005

Eikenberry, N., \& Smith, C. (2004). Healthful eating: Perceptions, motivations, barriers, and promoters in low-income Minnesota communities. J ournal of the American Dietetic Association, 104(7), 1158-1161. doi: http:// dx.doi.org/ 10.1016/j.jada.2004.04.023

Fitzpatrick-Lewis, D., Ganann, R., Krishnaratne, S., Ciliska, D., Kouyoudjian, F., \& Hwang, S. (2011). Effectiveness of interventions to improve the health and housing status of homeless people: a rapid review. BMC Public Health, 11 (1),1. doi: 10.1186/ 1471-2458-11-638 
Hayward, E., Ibe, C., Young, J . H., Potti, K., J ones, P., Pollack, C. E., \&Gudzune, K. A. (2015). Linking social and built environmental factors to the health of public housing residents: a focus group study. BMC Public Health, 15, 351. http:// doi.org/ 10.1186/ s12889-015-1710-9

Henwood, B., Stanhope, V., Brawer, R., Weinstein, L., Lawson, J ., Stwords, E., \& Crossan, C. (2013). Addressing chronic disease within supportive housing programs. Progress in Community Health Partnerships: Research, Education, and Action, 7(1), 67- 75. http:// doi.org/ 10.1353/ cpr.2013.0005

Housing Services for Women. (2016). The Center for Transforming Lives. Retrieved from https:/ / www.transforminglives.org/ housing-services

Keene D.\&Geronimus T. (2011). Community-based support among African American public housing residents. J ournal of Urban Health. 88: 41- 53. doi:

10.1007/s11524-010-9511-z

Manness, D. \& Khan, M. (2014). Care of the homeless: An overview. American Family Physician. 89(8), 634-640. Retrieved from http:/ / www.aafp.org/afp/ 2014/ 0415/ p634.html

Mayor's Advisory Commission on Homelessness. (2008). Directions Home: Making homelessness rare, short-term and non-recurring in Fort Worth, Texas within ten years. Retrieved from:

http:/ / www.directionshome.org/ plan/ DirectionsHome.pdf.

Muirhead, V., Quiñonez, C., Figueriredo, R., \&Locker, D. (2009). Oral health disparities and food insecurity in working poor Canadians. Community Dentistry and Oral Epidemiology, 37(4), 294-304. doi: 10.1111/j.1600-0528.2009.00479.x. 
Rodriguez J ., Applebaum J ., Stephenson-Hunter C., Tinio A., \& Shapiro A. (2013). Cooking, healthy eating, fitness and fun (CHEFFs): Qualitative evaluation of a nutrition education program for children living at urban family homeless shelters. American J ournal of Public Health, 103(S2), S361-S367. doi:10.2105/ AJ PH.2013.301558.

Rustad, C., \& Smith, C. (2013). Nutrition knowledge and associated behavior changes in a holistic, short-term nutrition education intervention with low-income women. J ournal of Nutrition Education and Behavior, 45(6), 490-498. Retrieved from http:/ / experts.umn.edu/ en/ publications/ nutrition-knowledgeand-associated-behavior-changes-in-a-holistic-shortterm-nutrition-educationintervention-with-lowincome-women(f6f525a1-e602-4d1e-bf186e9838626ce8).html

Slesnick, N., \&Erdem, G. (2012). Intervention for homeless, substance abusing mothers: Findings from a non-randomized pilot. J ournal of Behavioral Medicine, 38(2), 36-48. doi:10.1080/08964289.2012.657724

Speck, B. J ., Hines-Martin, V., Stetson, B. A., \&Looney, S. W. (2007). An environmental intervention aimed at increasing physical activity levels in low-income women. The J ournal of Cardiovascular Nursing, 22(4), 263-271. Retrieved from http:// www.ncbi.nlm.nih.gov/ pubmed/ 17589277

Tarrant County Homeless Coalition. (2014). How many people are homeless in Tarrant \& Parker county [Chart]. In the November 2014 Quarterly Report. Retrieved from http:/ / www.ahomewithhope.org/ staff/local-data-research/ quarterlyreports-snapshots/ 
Texas Christian University Student Development Services. (2015). Chancellor's Leadership Program. Retrieved from http:// sds.tcu.edu/ students/leadership/leadership-center/ chancellorsleadership-program/

United States Department of Agriculture. (2015). MyPlate. Retrieved from http:// www.choosemyplate.gov/ about-us

U.S. Department of Housing and Urban Development. (2011). The 2010 Annual Homeless Assessment Report to Congress. Washington, DC. [2010 AHAR]

Wallace, B. B., \& MacEntee, M. I. (2012). Access to dental care for low-income adults: Perceptions of affordability, availability and acceptability. J ournal of Community Health, 37(1), 32-39. Retrieved from http:// corescholar.libraries.wright.edu/ cgi/ viewcontent.cgi?article=1099\&contex $\mathrm{t}=\mathrm{mph}$

Wardle, J ., \& Steptoe, A. (2003). Socioeconomic differences in attitudes and beliefs about healthy lifestyles. J ournal of Epidemiology and Community Health,57(6), 440-443. doi:10.1136/jech.57.6.440

Withall, J ., J ago, R., \&Fox, K. R. (2011). Why some do but most don't. Barriers and enablers to engaging low-income groups in physical activity programmes: A mixed methods study. BMC Public Health, 11(1), 507. doi:10.1186/1471-2458-11507

Yousey, Y., Leake, J ., Wdowik, M., \&J anken, J . K. (2007). Education in a homeless shelter to improve the nutrition of young children. Public Health Nursing, 24(3), 249-255. 10.1111/j.1525-1446.2007.00631.x 


\section{Appendix A}

\section{Session Lesson Plans and Objectives}

\section{Session 1: Nutrition Labels Objectives:}

\begin{tabular}{|c|c|c|c|}
\hline Activity & Time & Lesson Plan & Handouts/Supplies \\
\hline $\begin{array}{l}\text { Ice } \\
\text { Breaker } \\
\text { Activity }\end{array}$ & 10 minutes & $\begin{array}{l}\text { Introduce ourselves and our story. Get on their level. Go around and say } \\
\text { your name, your favorite food, and describe the food you ate last week in } \\
\text { one word. Have you ever read a nutrition label? Do you eat foods with a } \\
\text { nutrition label? This activity will help us understand our food more. }\end{array}$ & \\
\hline $\begin{array}{l}\text { Ice } \\
\text { Cream } \\
\text { Label } \\
\text { Activity }\end{array}$ & 15 minutes & $\begin{array}{l}\text { Hand out the handouts with nutrition label and test. Give them } 5 \\
\text { minutes to take the test independently (a minute per question). Explain } \\
\text { each question. } \\
\text { 1. If you eat one serving size, how many calories will you } \\
\text { eat? } \\
\text { 2. If you eat the entire container of ice cream, how many } \\
\text { calories will you eat? } \\
\text { 3. Does this ice cream contain more fat or carbohydrates? } \\
\text { 4. If you usually eat } 2500 \text { calories in a day, what percentage } \\
\text { of your daily value of calories will you be eating if you eat } \\
\text { one serving of ice cream? } \\
\text { 5. Pretend that you are allergic to the following items: } \\
\text { Penicillin, peanuts, latex gloves, and bee stings. Is it safe for } \\
\text { you to eat this ice cream? Why or why not? }\end{array}$ & $\begin{array}{l}\text { Ice Cream } \\
\text { Nutrition Label } \\
\text { Pre-test } \\
\text { Pens/Pencils }\end{array}$ \\
\hline $\begin{array}{l}\text { How to } \\
\text { Read a } \\
\text { Nutritio } \\
\text { n Label }\end{array}$ & 15 minutes & $\begin{array}{l}\text { - Start with the serving size and servings per container. It is found on } \\
\text { the top portion of the label. It is important because all the other } \\
\text { information is based on the serving size. It is important to look at the } \\
\text { serving size because overeating certain foods is common. } \\
\text { - Next, check the calories. The calories shown are the calorie per } \\
\text { servings, not the total amount in the container. Next, look at the } \\
\text { calories from fat. That indicates how many of the calories in the } \\
\text { serving come from fat. You want that number of calories to be low } \\
\text { (the lower the number, the better). } \\
\text { Take a look at the next section of the label. On the left hand side, you } \\
\text { will see the nutrient and the amount of it found in the food. On the } \\
\text { right hand side, you will see the daily value \%. The total daily value } \\
\text { is of } 100 \% \text {. You should be consuming a certain amount of each } \\
\text { nutrient every day (that amount being the } 100 \% \text { ). The daily value \% } \\
\text { shows how much of that } 100 \% \text { of the nutrient one serving of this } \\
\text { food contains. } 5 \% \text { or less is low and } 20 \% \text { or more is high. } \\
\text { Next, take a look at the total fat, cholesterol, and sodium. These } \\
\text { nutrients are necessary, but you want to limit them because too } \\
\text { much of them in your diet can be bad. You really want to look for } \\
\text { foods that are low in trans fat and saturated fat (ideally, when } \\
\text { combined, they should be less than } 5 \text { grams per serving). }\end{array}$ & $\begin{array}{l}\text { Nutrition Label } \\
\text { Poster } \\
\text { Pass out "Nutrition } \\
\text { Label Notes" }\end{array}$ \\
\hline
\end{tabular}




\begin{tabular}{|c|c|c|c|}
\hline & & $\begin{array}{l}\text { - If you look at the carbohydrate section, it is divided into fiber and } \\
\text { sugar. You want high amounts of fiber and low amounts of sugar. } \\
\text { - } \quad \text { Fext, you can see the amount of protein in the food. } \\
\text { vitaming the last portion of the nutrition food label shows the } \\
\text { amounts of vitamin and minerals is important because these } \\
\text { nutrients are vital in your diet. High percentages daily values for } \\
\text { these nutrients are good (the higher, the better). } \\
\text { - Last, take a look at the ingredients section. This shows all the } \\
\text { different ingredients that are found in the food. They are listed in } \\
\text { descending order based on weight. The higher up the ingredient is } \\
\text { on the list, the most of it there is. The final line of the ingredients is } \\
\text { normally bolded and that shows the allergens found in the food } \\
\text { (what people are commonly allergic to:milk, soy, gluten, peanuts). }\end{array}$ & \\
\hline $\begin{array}{l}\text { Interacti } \\
\text { ve } \\
\text { nutrition } \\
\text { label } \\
\text { reading }\end{array}$ & 15 minutes & $\begin{array}{l}\text { Divide the class into partners. Give each pairing a nutrition label with a } \\
\text { handout of questions. Have the partners complete the questions and } \\
\text { then compare and explain their answers with another pair. }\end{array}$ & $\begin{array}{l}\text { Nutrition label } \\
\text { post-test partner } \\
\text { activity handout }\end{array}$ \\
\hline $\begin{array}{l}\text { Why is } \\
\text { this } \\
\text { importa } \\
\text { nt? }\end{array}$ & 10 minutes & $\begin{array}{l}\text { Do you all think it's important to be able to read a nutrition label? Why } \\
\text { or why not? As a group, create a list of } 6 \text { reasons why it is important to } \\
\text { them personally to have the knowledge to read a label. Next, discuss } \\
\text { realistic scenarios where the women will read nutrition labels. Have } \\
\text { each pair write } 2 \text { scenarios on their nutrition label activity and then ask } \\
\text { for volunteers to share their scenarios. }\end{array}$ & $\begin{array}{l}\text { Chart paper to } \\
\text { make list and } \\
\text { markers } \\
\text { Collect post-test at } \\
\text { end }\end{array}$ \\
\hline Recap & 5 minutes & $\begin{array}{l}\text { Today, we looked at how to read a nutrition label. When reading one, } \\
\text { start by looking at the serving size and calories per serving. Then, take a } \\
\text { look at the different nutrients in the food. Be sure your food is low in fat, } \\
\text { cholesterol, and sodium and high in fiber and vitamins. Then, look at } \\
\text { the ingredients to detect any things you might be allergic to. } \\
\text { Keep the worksheets in your binder. Next week, we will continue by } \\
\text { talking about MyPlate and portion control. }\end{array}$ & Evaluation Survey \\
\hline
\end{tabular}

By the end of this session participants will be able to:

1. Identify the nutrient content of foods by reading the nutrition label. (Knowledge)

2. Calculate the calorie content in a unit of food and compare it with the calorie content of one serving size. (Knowledge/ Behavior)

3. Express the value and importance of reading nutrition labels. (Attitude)

4. Partner with a friend to read a nutrition label. (Behavior/ Social Support/Subjective Norm)

5. Describe situations in which they will read nutrition labels. (Intention)

6. Express confidence in their ability to read nutrition labels. (Perceived behavioral control)

Evaluation of Objectives:

1. $85 \%$ of the partner pairs will correctly determine the nutrient content of a food when given the label, as measured by the ice cream label health literacy assessment form.

2. $75 \%$ of the partner pairs will correctly calculate the calorie content in a unit of food and compare it with the calorie content of one serving size, as measured by paired completion of the nutrition label partner activity form. 
3. $80 \%$ of participants will answer "Agree" or "Strongly Agree" to numbers 1 and 2 on the evaluation survey.

4. $95 \%$ of participants will complete the nutrition label partner activity, and $80 \%$ of participants will answer "Agree" or "Strongly Agree" to number 3 and 4 on the evaluation survey.

5. $90 \%$ of pairs will list 2 situations where they plan/intend to read nutrition labels and $80 \%$ of participants will answer "Agree" or "Strongly Agree" to number 6 and 8 on the evaluation survey.

6. $80 \%$ of participants will answer "Agree" or "Strongly Agree" to numbers 5 and 7 on the evaluation survey.

\section{Session 2: Portion Control and Easy, Healthy Living Tips}

\section{Objectives:}

By the end of this session participants will be able to:

1. List 2 easy food swaps that they plan to make to create a healthier meal. (Intention)

2. Work in groups to color and correctly fill out a well-proportioned plate. (Knowledge/ Behavior)

3. Express confidence in their ability to plan a healthy meal. (Perceived Behavioral Control)

4. Express the value and importance of controlling portion size and choosing healthier foods. (Attitude)

5. Share a healthy eating tip with another member of the class. (Social Support/ Subjective Norm)

\begin{tabular}{|l|l|l|l|}
\hline Activity & Time & Lesson Plan & $\begin{array}{l}\text { Handouts/Supplie } \\
\text { s }\end{array}$ \\
\hline $\begin{array}{l}\text { Introduction } \\
\text { to lesson }\end{array}$ & $\begin{array}{l}5 \\
\text { minutes }\end{array}$ & $\begin{array}{l}\text { First we want to talk with you about the difference between high } \\
\text { calorie food and high nutrient food. Calories are a form of energy. So } \\
\text { you can have a food really high in calories without it being good for } \\
\text { your body. Have you ever eaten a donut and were hungry within an } \\
\text { hour? While there are a lot of calories in donuts, they don't keep us } \\
\text { full for very long. These calories or energy are coming from sugar } \\
\text { and fat. Foods with lots of nutrients (eggs, oatmeal) have their } \\
\text { calories coming from protein. Protein keeps our body healthier and } \\
\text { full longer than sugar does. This is a double bonus because it's better } \\
\text { for our bodies and gives us more energy. Explain diagram }\end{array}$ & $\begin{array}{l}\text { Diagram } \\
\text { different } \\
\text { same calories but } \\
\text { one is much more } \\
\text { food }\end{array}$ \\
\hline
\end{tabular}




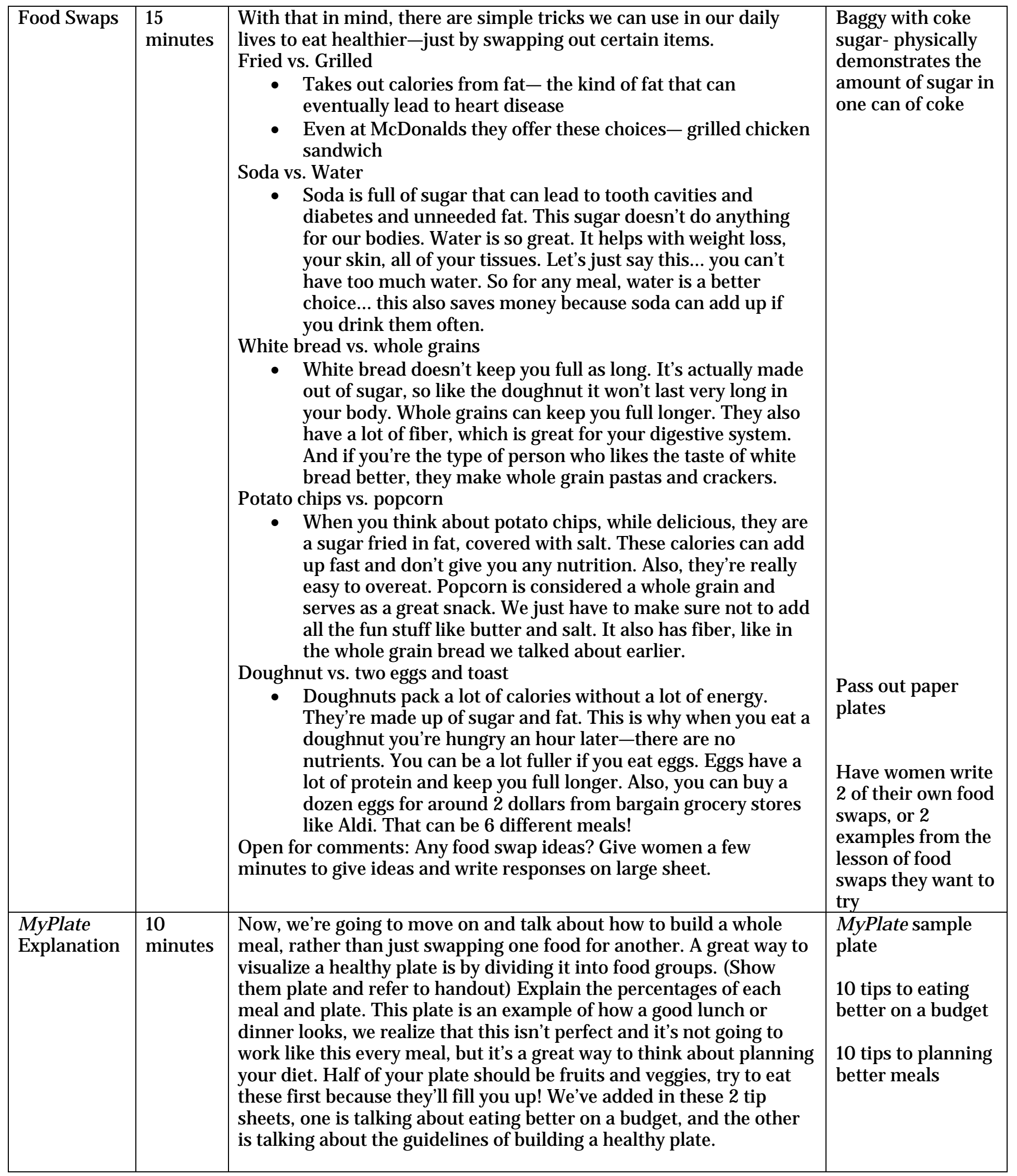




\begin{tabular}{|l|l|l|l|}
\hline $\begin{array}{l}\text { MyPlate } \\
\text { Building }\end{array}$ & $\begin{array}{l}10 \\
\text { minutes }\end{array}$ & $\begin{array}{l}\text { Work in a group to color an ideal plate with the correct portions, } \\
\text { using what we just talked about. Label the different proportions with } \\
\text { a certain color and inside each piece, write a food that you enjoy that } \\
\text { you could place on the plate in the correct portion. Share ideas with } \\
\text { other groups. }\end{array}$ & $\begin{array}{l}\text { Paper plates and } \\
\text { markers }\end{array}$ \\
\hline Simple Tips & $\begin{array}{l}5 \\
\text { minutes }\end{array}$ & $\begin{array}{l}\text { Half of your grains should be coming from a whole grain source. } \\
\text { Make sure it's whole grain or whole wheat, not multigrain. If you're } \\
\text { picking out a good bread, it should have fiber in it! Like we talked } \\
\text { about last week, fiber is great for you! When eating/ drinking dairy, } \\
\text { try to keep it low fat- skim milk and low fat yogurt are best. }\end{array}$ & $\begin{array}{l}\text { When it comes to vegetables and fruit, fresh, frozen, or canned are } \\
\text { all good! Canned vegetables tend to have more sodium, and canned } \\
\text { fruit more sugar, but they're still options and a good source of } \\
\text { vitamins. }\end{array}$ \\
\hline & $\begin{array}{l}\text { We've included planned, inexpensive meals that you can try that } \\
\text { have good ratios. It's possible to eat healthy and on a budget! }\end{array}$ & $\begin{array}{l}\text { Sample Meal } \\
\text { Handout }\end{array}$ \\
\hline
\end{tabular}

Evaluation of Objectives:

1. $80 \%$ of participants will answer "Agree" or "Strongly Agree" to numbers 6 and 8 on the evaluation survey, and $90 \%$ of participants will list 2 easy food swaps that they plan to make to create a healthier meal as measured by completion of the Food Swap Activity on the back of the paper plate.

2. $95 \%$ of participants will correctly label and complete the MyPlate building activity.

3. $80 \%$ of participants will answer "Agree" or "Strongly Agree" to numbers 5 and 7 on the evaluation survey.

4. $80 \%$ of participants will answer "Agree" or "Strongly Agree" to numbers 1 and 2 on the evaluation survey.

5. $90 \%$ of participants will answer "Agree" or "Strongly Agree" to numbers 3 and 4 on the evaluation survey and $60 \%$ of participants will share a food swap idea, as measured by the paper chart list.

\section{Session 3: Oral Care and Foot Care}

\section{Objectives:}

By the end of this session participants will be able to:

1. List 3 ways that they can improve their mouth or foot health. (Knowledge/ Behavior) 
2. Express the value and importance of maintaining healthy teeth and feet. (Attitude)

3. Demonstrate correct foot care maintenance alongside their peers. (Behavior/ Subjective Norm)

4. Articulate intention to make an appointment with their dentist or dental clinic in the next 6 months. (Intention)

5. Express confidence in their ability to perform oral and foot care. (Perceived behavioral control)

\begin{tabular}{|c|c|c|c|}
\hline Activity & Time & Lesson Plan & $\begin{array}{l}\text { Handouts/Sup } \\
\text { plies }\end{array}$ \\
\hline $\begin{array}{l}\text { Introduction } \\
\text { and Overview }\end{array}$ & 2 minutes & $\begin{array}{l}\text { Today we're going to talk about oral care and foot care. First, } \\
\text { we want to have a conversation about how to properly care for } \\
\text { your smile. J ust like any other part of your body, it's } \\
\text { important for us to keep our mouths clean and healthy. The } \\
\text { easiest way to do this is by BRUSHING! }\end{array}$ & $\begin{array}{l}\text { Hand out the } \\
\text { information } \\
\text { sheets }\end{array}$ \\
\hline $\begin{array}{l}\text { Brushing } \\
\text { Instructions }\end{array}$ & 5 minutes & $\begin{array}{l}\text { Dentists say that brushing your teeth } 2 \text { times a day, once in } \\
\text { the morning and once at night is the best way to keep our } \\
\text { mouths healthy. When you brush your teeth, you should brush } \\
\text { them for } 2 \text { minutes (the ABCs } 4 \text { times). If you can only brush } \\
\text { your teeth once a day, you should do it at night to remove all } \\
\text { of the bacteria from your teeth before you go to bed. } \\
\text { o How to brush teeth-demonstration on tooth model } \\
\text { o Flossing is also important because it decreases your } \\
\text { chance of getting gum disease and other mouth problems }\end{array}$ & $\begin{array}{l}\text { Tooth model } \\
\text { Brushes } \\
\text { Pass out } \\
\text { supplies } \\
\text { Point to photo } \\
\text { on poster/ } \\
\text { handout }\end{array}$ \\
\hline $\begin{array}{l}\text { Consequences } \\
\text { of poor oral } \\
\text { hygiene }\end{array}$ & 5 minutes & $\begin{array}{l}\text { o It's good to see a dentist because they can thoroughly } \\
\text { clean your teeth and prevent cavities. } \\
\text { o “Does anyone know what a cavity is, or how they form?” } \\
\text { o We all have bacteria throughout our bodies, on our skin, } \\
\text { in our eyes, nose, and mouth. That's just part of life. In } \\
\text { your mouth, bacteria stick to the surface of your teeth. } \\
\text { When you eat carbohydrates, or sugars, the bacteria are } \\
\text { able to eat those sugars which causes them to make acid. } \\
\text { This acid is very harmful to your teeth and can cause } \\
\text { them to be more vulnerable to getting a cavity. } \\
\text { o If you eat a lot of sugary snacks throughout the day, it } \\
\text { can increase your chance of getting a cavity because your } \\
\text { mouth has less time to repair your teeth after they've } \\
\text { been exposed to acid. } \\
\text { o When you don't brush your teeth, there's more plaque, or } \\
\text { the film of bacteria, which will catch more sugar and } \\
\text { break down your teeth even more. }\end{array}$ & \\
\hline
\end{tabular}




\begin{tabular}{|c|c|c|c|c|}
\hline $\begin{array}{l}\text { Smoking and } \\
\text { Oral Care }\end{array}$ & 5 minutes & $\begin{array}{l}0 \\
0 \\
0\end{array}$ & $\begin{array}{l}\text { Smoking causes a lot of damage to your body. Whether } \\
\text { it's your lungs, skin, hair, or even your teeth. } \\
\text { When you smoke you can develop gum disease which can } \\
\text { cause tooth loss. It also increases your chance of getting } \\
\text { cancer in your mouth. } \\
\text { It's important to quit smoking for many reasons, } \\
\text { especially dental reasons. But we understand that it's } \\
\text { hard to quit. If you do smoke, it's even MORE important } \\
\text { to brush your teeth and to do it for } 3 \text { minutes which is } \\
\text { more than the normal } 2 \text {. } \\
\text { Also, check your mouth for any sores or spots that look } \\
\text { different because that can be a sign of cancer. }\end{array}$ & \\
\hline $\begin{array}{l}\text { Diabetes and } \\
\text { Oral Care }\end{array}$ & 3 minutes & & $\begin{array}{l}\text { Certain illnesses can cause people to have a greater risk } \\
\text { of having oral problems. } \\
\text { Diabetes is a very common illness in our society and } \\
\text { community today. } \\
\text { People with diabetes are more likely to develop } \\
\text { infections. This is because the increased sugar in your } \\
\text { blood damages the way that infection-fighting cells can } \\
\text { move around the body. This means that a diabetic } \\
\text { person's body can't fight the bacteria in your mouth as } \\
\text { well. } \\
\text { you have diabetes or know someone with diabetes it's even } \\
\text { ORE important to brush and floss every day. When you do } \\
\text { to get your teeth cleaned, make sure you tell the person } \\
\text { to's cleaning them that you have diabetes. }\end{array}$ & \\
\hline $\begin{array}{l}\text { Practical } \\
\text { ways to keep } \\
\text { teeth clean }\end{array}$ & 2 minutes & & $\begin{array}{l}\text { Chew sugar free gum instead of sugar gum-explain why } \\
\text { Rinse out your mouth after you eat a sugary meal or } \\
\text { snack- even if it's just swish and spit! } \\
\text { Brush your teeth twice a day for } 2 \text { minutes } \\
\text { *mention that brushing might be painful at first, but it } \\
\text { will feel less painful over time } \\
\text { Floss once a day } \\
\text { Avoid soda as much as possible since it can cause } \\
\text { breakdown of your teeth }\end{array}$ & \\
\hline Dentists & 5 minutes & & $\begin{array}{l}\text { One of the best ways to keep our teeth healthy is seeing a } \\
\text { dentist! } \\
\text { Ask: Raise your hand if you have ever been to a dentist? } \\
\text { How about if you have been in the last three years. Keep } \\
\text { your hand raised if you have been in the past year. How } \\
\text { many have been in the past } 6 \text { months? } \\
\text { We understand it is hard to see a dentist and easy to } \\
\text { forget to make appointments, and might not be on the } \\
\text { top of your priority list, but it is important. } \\
\text { Listed here we have some inexpensive options to get your } \\
\text { teeth cleaned! }\end{array}$ & $\begin{array}{l}\text { Dental } \\
\text { Referral Sheet }\end{array}$ \\
\hline
\end{tabular}




\begin{tabular}{|c|c|c|c|c|}
\hline $\begin{array}{l}\text { Foot care } \\
\text { Overview }\end{array}$ & 2 minutes & 0 & $\begin{array}{l}\text { Another part of our body that is often overlooked is our } \\
\text { feet. People with diabetes are more likely to have } \\
\text { problems with their feet, but even if you don't have } \\
\text { diabetes, we're going to talk about some easy ways to } \\
\text { keep our feet clean and healthy. }\end{array}$ & \\
\hline & 1 minute & 0 & $\begin{array}{l}\text { We know that many of you all are on your feet for many } \\
\text { hours a day. Although its important to get moving and } \\
\text { exercise, long hours on our feet or wearing shoes that } \\
\text { don't fit, or walking around barefoot can cause some } \\
\text { serious damage to our feet. }\end{array}$ & \\
\hline $\begin{array}{l}\text { Tips for } \\
\text { healthier } \\
\text { feet }\end{array}$ & 5 minutes & $\begin{array}{l}0 \\
0 \\
0\end{array}$ & $\begin{array}{l}\text { If you stand for long hours, any easy trick to stretch and } \\
\text { relax your muscles is to do calf raises (demonstrate) and } \\
\text { runner's stretch (demonstrate). } \\
\text { Elevate your feet at the end of the day at equal height to } \\
\text { your hips if you can. This could be putting a pillow or } \\
\text { blanket underneath your feet to lower the amount of } \\
\text { swelling. } \\
\text { If you stand, try to wiggle your toes in your shoes or shift } \\
\text { your weight from one side to another to help with pain } \\
\text { and swelling. }\end{array}$ & \\
\hline $\begin{array}{l}\text { Diabetes } \\
\text { and Foot } \\
\text { Care }\end{array}$ & 5 minutes & $\begin{array}{l}0 \\
0\end{array}$ & $\begin{array}{l}\text { Another way that our feet are damaged is because of } \\
\text { diabetes. Diabetes is a really common condition today, } \\
\text { but it can cause some serious effects on different parts of } \\
\text { our bodies, especially our feet. } \\
\text { This is because diabetes can cause our feet to loose } \\
\text { feeling or tingle, so you might not realize that your foot is } \\
\text { injured, since you can't feel it. }\end{array}$ & $\begin{array}{l}\text { Foot Care } \\
\text { Handout }\end{array}$ \\
\hline Pedicure & $\begin{array}{l}20 \\
\text { minutes }\end{array}$ & Foo & Care Activity & $\begin{array}{l}\text { Foot care } \\
\text { supplies }\end{array}$ \\
\hline
\end{tabular}

Evaluation of Objectives:

1. $80 \%$ of participants will list 3 ways that they can improve their mouth or foot health as measured by number 9 on the evaluation survey.

2. $90 \%$ of participants will answer "Agree" or "Strongly Agree" to numbers 1 and 2 on the evaluation survey.

3. $80 \%$ of participants will participate in the foot care activity as measured by counting the number of participants that remain for the last activity.

4. $80 \%$ of participants will answer "Agree" or "Strongly Agree" to numbers 6 and 8 on the evaluation survey.

5. $90 \%$ of participants will answer "Agree" or "Strongly Agree" to numbers 5 and 7 on the evaluation survey. 


\section{Session 4: Exercise for the Mind, Body, \& Soul}

\section{Objectives:}

By the end of this session participants will be able to:

1. Express the value and importance of regular exercise as it relates to overall health. (Attitude)

2. Share exercise goals with other peers, and participate in an instructed exercise course. (Subjective Norm)

3. Create exercise goals for themselves for the next month. (Intention)

4. Express confidence in their ability to incorporate exercise into weekly routine (Perceived Behavioral Control).

\begin{tabular}{|c|c|c|c|}
\hline Activity & Time & Lesson Plan & Handouts/Supplies \\
\hline $\begin{array}{l}\text { Introducti } \\
\text { on }\end{array}$ & $\begin{array}{l}2 \\
\text { minutes }\end{array}$ & $\begin{array}{l}\text { Introduce yourselves and talk about what you will be } \\
\text { teaching today. We are going to be talking about the } \\
\text { importance of exercise, easy exercises to incorporate } \\
\text { in your daily life, and we're going to end with a yoga } \\
\text { class for y'all! Our goal for you today is to incorporate } \\
\text { exercise in your life and recognize the benefits! }\end{array}$ & \\
\hline $\begin{array}{l}\text { Self- } \\
\text { Reflection }\end{array}$ & $\begin{array}{l}2 \\
\text { minutes }\end{array}$ & $\begin{array}{l}\text { How many of you exercise on a daily basis? And what } \\
\text { do you do for exercise? [then respond accordingly] }\end{array}$ & \\
\hline $\begin{array}{l}\text { Importanc } \\
\text { e of } \\
\text { Exercise }\end{array}$ & $\begin{array}{l}10 \\
\text { minutes }\end{array}$ & $\begin{array}{l}\text { - Mind, Body, Soul } \\
\text { - Mind: physical activity releases endorphins } \\
\text { which are known to make you happier and } \\
\text { more relaxed; regular physical activity helps } \\
\text { you sleep better at night (falling asleep easier } \\
\text { and staying asleep longer); exercise helps clear } \\
\text { your mind. } \\
\text { Body: exercise increases your energy level by } \\
\text { delivering oxygen and nutrients to your whole } \\
\text { body; exercise keeps you healthy! It helps } \\
\text { prevent heart disease and stoke by } \\
\text { strengthening your heart muscle, lowering } \\
\text { blood pressure, lowering bad cholesterol, and } \\
\text { improving blood flow; Strengthening exercises } \\
\text { strengthen your bones and prevents bone loss } \\
\text { that is associated with aging (major problem } \\
\text { for aging women is osteoporosis which is the } \\
\text { breakdown of bones); Exercise can reduce } \\
\text { body fat and prevent obesity, which is a major } \\
\text { cause for other diseases as you age; exercising } \\
\text { regularly can manage or prevent diabetes; } \\
\text { exercise increases metabolism which will help } \\
\text { you maintain or lose weight. }\end{array}$ & \\
\hline
\end{tabular}




\begin{tabular}{|c|c|c|c|}
\hline & & $\begin{array}{l}\text { Soul: exercising is a great way to socialize; it } \\
\text { can help you relieve stress and reduce } \\
\text { depression and anxiety; Exercise can even } \\
\text { increase your self-confidence! }\end{array}$ & \\
\hline $\begin{array}{l}\text { Teaching } \\
\text { Exercises }\end{array}$ & $\begin{array}{l}20 \\
\text { minutes }\end{array}$ & $\begin{array}{l}\text { Demonstrate and have them do it with us: } \\
\text { - Pushups } \\
\text { - Squats } \\
\text { - Lunges } \\
\text { - "Weight" Lifting (using cans or bottles or no } \\
\text { - } \text { - Sit Uph } \\
\text { - Allow time for women to demonstrate or share } \\
\text { their favorite exercise moves and encourage } \\
\text { others to join them. }\end{array}$ & \\
\hline $\begin{array}{l}\text { How to } \\
\text { Incorpora } \\
\text { te it in } \\
\text { your daily } \\
\text { life }\end{array}$ & $\begin{array}{l}10 \\
\text { minutes }\end{array}$ & $\begin{array}{l}\text { - It's important to set aside at least } 30 \text { minutes a } \\
\text { day for physical activity } \\
\text { - Physical activity doesn't have to be the } \\
\text { exercises we just taught, it can be part of your } \\
\text { daily activities: such as taking your kids to the } \\
\text { park, taking the stairs, shopping for groceries, } \\
\text { and walking to the food bank } \\
\text { - Try to make exercising a habit! Find a way that } \\
\text { suits you and your schedule } \\
\text { - For weights you can use canned food or water } \\
\text { bottles and chairs are useful for many different } \\
\text { exercises } \\
\text { - Introduce goal sheets and have women fill out } \\
2 \text { copies and then share their healthy mind, } \\
\text { body, and soul goals with a partner. }\end{array}$ & $\begin{array}{l}\text { Have them set a goal } \\
\text { for themselves } \\
\text { Goal sheets }\end{array}$ \\
\hline Summary & $\begin{array}{l}3 \\
\text { minutes }\end{array}$ & $\begin{array}{l}\text { - In conclusion, exercising } 30 \text { minutes a day can } \\
\text { improve your mind, body, and soul and help } \\
\text { promote a healthy lifestyle } \\
\text { - We have provided you a few exercise } \\
\text { techniques to get you started! And once we } \\
\text { finish up you will have the opportunity to take } \\
\text { a yoga class (another fun way to exercise) } \\
\text { - Any questions? }\end{array}$ & \\
\hline Yoga & $\begin{array}{l}30 \\
\text { minutes }\end{array}$ & Yoga Class! & Yoga instructor \\
\hline
\end{tabular}


Objective Evaluation:

1. $80 \%$ of participants will answer "Agree" or "Strongly Agree" to numbers 1 and 2 on the evaluation survey.

2. $90 \%$ of participants will share exercise goals with other peers and participate in an instructed exercise course, as measured by an observer's tally and $80 \%$ of participants will answer "Agree" or "Strongly Agree" to numbers 3 and 4 on the evaluation survey.

3. $90 \%$ of participants will complete the exercise goals sheet as measured by the goal sheets and $80 \%$ of participants will answer "Agree" or "Strongly Agree" to numbers 6 and 8 on the evaluation survey.

4. $80 \%$ of participants will answer "Agree" or "Strongly Agree" to numbers 5 and 7 on the evaluation survey.

\section{Session 5: Cooking on a Budget}

\section{Objectives:}

By the end of this session participants will be able to:

1. Express the value and importance of cooking at home recipes. (Attitude)

2. Participate in preparation of the meal alongside peers. (Subjective Norm)

3. Plan to prepare a meal using the resources from the lesson in the next month. (Intention)

4. Express confidence in their ability to read nutrition labels. (Perceived Behavioral Control)

\begin{tabular}{|c|c|c|c|}
\hline Activity & Time & Lesson Plan & $\begin{array}{l}\text { Handouts/Su } \\
\text { pplies }\end{array}$ \\
\hline $\begin{array}{l}\text { Introdu } \\
\text { ction }\end{array}$ & 3 minutes & $\begin{array}{l}\text { Introduce yourself, and ask how comfortable the group is with } \\
\text { cooking and knife skills. Give an overview of the lesson: } \\
\text { - How to make a meal under } \$ 5.00 \\
\text { - Review tip sheet } \\
\text { - Review } 6 \text { recipes } \\
\text { - Assign tasks for cooking demonstration } \\
\text { - Eat! }\end{array}$ & \\
\hline $\begin{array}{l}\text { Tip } \\
\text { Sheet }\end{array}$ & $\begin{array}{l}10 \\
\text { minutes }\end{array}$ & $\begin{array}{l}\text { First, we're going to talk about a few at-home tips that can } \\
\text { help you spend less time and money while still preparing } \\
\text { meals at home. One trick that can save you some money is } \\
\text { buying vegetables that are in season. For example, in the fall } \\
\text { time the vegetables that are in season are things like carrots, } \\
\text { squash, brussel sprouts, pumpkin, potatoes, cauliflower, and } \\
\text { turnips. Because these vegetables are at the peak of the } \\
\text { season, there are more of them available which will make } \\
\text { them cheaper! } \\
\text { However, if you feel like fresh vegetables don't suit your taste } \\
\text { or lifestyle, canned vegetables can be a good replacement. } \\
\text { While they typically have more salt, if you rinse them out } \\
\text { before cooking them it can help to take some of the salt out. }\end{array}$ & Tip Sheet \\
\hline
\end{tabular}




\begin{tabular}{|c|c|c|c|}
\hline & & $\begin{array}{l}\text { Using leftovers is also a great way to save some money! If you } \\
\text { don't eat all of your meal in one serving, you can always use } \\
\text { parts of it to cook up something new! } \\
\text { Looking at grocery store ads can help you find out what that } \\
\text { store's special deals are for the week- which can help you } \\
\text { decide which foods to buy that week. } \\
\text { Another great way to eat healthier and still be mindful of your } \\
\text { budget is to prepare meals for yourself rather than buying pre- } \\
\text { packaged meals. Oftentimes, the prepackaged meals have tons } \\
\text { of preservatives and additives that can make them worse than } \\
\text { fast food. They're also more expensive than the at-home } \\
\text { version too! } \\
\text { There are a few more tips on that sheet we handed out, but we } \\
\text { would like to give you all some time to share some of your } \\
\text { healthy cooking secrets with each other! }\end{array}$ & \\
\hline $\begin{array}{l}\text { Recipe } \\
\text { Review }\end{array}$ & 5 minutes & $\begin{array}{l}\text { We printed out some recipes for you all to reference the next } \\
\text { time you get brave enough to enter the kitchen! These recipes } \\
\text { were found at the website "goodandcheap" and it has all sorts } \\
\text { of recipes that can be made for under } \$ 5 !\end{array}$ & $\begin{array}{l}\text { Recipe } \\
\text { handout }\end{array}$ \\
\hline $\begin{array}{l}\text { Cooking } \\
\text { Demons } \\
\text { tration }\end{array}$ & $\begin{array}{l}45 \\
\text { minutes }\end{array}$ & $\begin{array}{l}\text { Tonight, we will be makingJ ambalaya. It's a great option for } \\
\text { dinner because you're able to have leftovers for a while and } \\
\text { you also can fit a lot of your vegetables in one dish. } \\
\text { We will need volunteers for the following: } \\
\text { o Chop the onion } \\
\text { o Chop the bell pepper } \\
\text { o Chop the celery } \\
\text { o Chop the garlic } \\
\text { o Chop the chili pepper } \\
\text { o Chop the tomatoes } \\
\text { o Open the can of beans and rinse } \\
\text { o Measure each spice } \\
\text { Lead class in preparing this recipe while explaining tasks } \\
\text { throughout and giving tips on easy cooking skills. }\end{array}$ & $\begin{array}{l}\text { All } \\
\text { ingredients } \\
\text { Pots } \\
\text { Pans } \\
\text { Plates } \\
\text { Plasticware }\end{array}$ \\
\hline Eating & $\begin{array}{l}20 \\
\text { minutes }\end{array}$ & $\begin{array}{l}\text { Feedback on the recipe? What would you change if you were } \\
\text { to make this for yourself? }\end{array}$ & \\
\hline Recap & 5 minutes & $\begin{array}{l}\text { Today, we talked about tips for healthy grocery shopping that } \\
\text { doesn't break the bank. Look at your tip sheet next time before } \\
\text { you enter the grocery store so you can have a better plan! } \\
\text { Cooking for yourself is possible, it just takes time to plan it out } \\
\text { and enjoy! }\end{array}$ & $\begin{array}{l}\text { Evaluation } \\
\text { Survey }\end{array}$ \\
\hline
\end{tabular}

Evaluation of Objectives

1. $80 \%$ of participants will answer "Agree" or "Strongly Agree" to numbers 1 and 2 on the evaluation survey. 
2. $90 \%$ of participants will participate in preparation of the meal alongside peers, as measured by an observer's count.

3. $80 \%$ of participants will answer "Agree" or "Strongly Agree" to numbers 6 and 8 on the evaluation survey.

4. $80 \%$ of participants will answer "Agree" or "Strongly Agree" to numbers 5 and 7 on the evaluation survey.

Appendix B

Session Evaluation Tools

\section{Health Literacy Evaluation Tool}

1. Knowing more about reading nutrition labels will help me choose healthier foods. (Attitude)

3

4 5

Strongly Disagree Disagree Neither Agree nor Disagree Agree Strongly Agree 2. It is important to me to eat foods high in nutrients. (Attitude)

1 2

3

4 5

Strongly Disagree Disagree Neither Agree nor Disagree Agree Strongly Agree 3. People who are important to me think that I should read nutrition labels. (Subjective norm) 1 2

3

4 5

Strongly Disagree Disagree Neither Agree nor Disagree Agree Strongly Agree 4. It is expected of me that I know about the nutrients in my food. (Subjective norm) 1 2 3

4 5

Strongly Disagree Disagree Neither Agree nor Disagree Agree Strongly Agree

5. Whether or not I eat healthier foods is completely up to me. (Perceived Behavioral Control)

1

2

3

4 5

Strongly Disagree Disagree Neither Agree nor Disagree Agree Strongly Agree 
6. I plan to use this information about reading nutrition labels after coming to this class. (Behavioral Intention)

1

Strongly Disagree
2

Disagree
3

4

5

7. I feel confident that I can read and understand the information on a nutrition label. (Perceived Behavioral Control)
1
2
3
4
5

Strongly Disagree Disagree Neither Agree nor Disagree Agree Strongly Agree

8. Chances are that I will read a nutrition label before eating my food in the next week. (Behavioral Intention) 1 2 3 4 5

Strongly Disagree Disagree Neither Agree nor Disagree Agree Strongly Agree Portion Control and Easy Food Swaps Evaluation Tool

1. Knowing more about healthy alternatives will help me choose healthier foods. (Attitude)

1 2

3
4 5

Strongly Disagree Disagree Neither Agree nor Disagree Agree Strongly Agree 2. It is important to me to eat healthy, well-balanced meals. (Attitude)

1

Strongly Disagree

Disagree
3
4

3. People who are important to me think that I should eat balanced meals. (Subjective norm) 1 2 3 4 5

Strongly Disagree Disagree Neither Agree nor Disagree Agree Strongly Agree 4. It is expected of me that I know about building healthy meals. (Subjective norm) 1 2 3 4 5

Strongly Disagree Disagree Neither Agree nor Disagree Agree Strongly Agree 
5. Whether or not I plan a healthy meal is completely up to me. (Perceived Behavioral Control) 1 2 3 4 5

Strongly Disagree Disagree Neither Agree nor Disagree Agree Strongly Agree 6. I plan to use this information about portion sizes and proportions after coming to this class. (Behavioral Intention)

1 2 3

4 5

Strongly Disagree Disagree Neither Agree nor Disagree Agree Strongly Agree 7. I feel confident that I can plan a well-balanced meal. (Perceived Behavioral Control) 1 2 3 4 5

Strongly Disagree Disagree Neither Agree nor Disagree Agree Strongly Agree 8. Chances are that I will cook a meal based off of the plate diagram in the next week. (Behavioral Intention)

1

Strongly Disagree
2

Disagree
3

4

5

\section{Oral and Foot Care Evaluation Tool}

1. Knowing more about mouth and foot hygiene will help me improve my health. (Attitude)

Strongly Disagree Disagree Neither Agree nor Disagree Agree Strongly Agree 2. It is important to me to care for my mouth and feet. (Attitude)

1

2

Strongly Disagree $\quad$ Disagree
3

4 5 Neither Agree nor Disagree Agree Strongly Agree 
3. People who are important to me think that I should go to the dentist. (Subjective Norm)

1

2

3

Strongly Disagree Disagree Neither Agree nor Disagree Agree Strongly Agree

4. It is expected of me that I know about keeping my feet clean and groomed. (Subjective Norm)

1

2

3

Strongly Disagree Disagree Neither Agree nor Disagree Agree Strongly Agree

5. Whether or not I brush my teeth every day is completely up to me. (Perceived Behavioral Control)

1

2

3

4

5

Strongly Disagree Disagree Neither Agree nor Disagree Agree Strongly Agree

6. I plan to visit a dentist office or dental clinic in the next 6 months. (Behavioral Intention)

1

2

3

4

5

Strongly Disagree Disagree Neither Agree nor Disagree Agree Strongly Agree

7. I feel confident that I can properly care for my feet and mouth. (Perceived Behavioral Control)

1

2

3

4

5

Strongly Disagree Disagree Neither Agree nor Disagree Agree Strongly Agree

8. Chances are that I will use a foot care tip from the handout in the next week. (Behavioral Intention)

1 2

3

4

5

Strongly Disagree Disagree Neither Agree nor Disagree Agree Strongly Agree

9. List 3 ways that you can plan to improve the health of your mouth and teeth. 


\section{Exercise Evaluation Tool}

1. Knowing more about different types of exercise will help me be more active. (Attitude)

1
2

Strongly Disagree

Disagree

3

Neither Agree nor Disagree
4

Agree

Strongly Agree

2. It is important to me to exercise. (Attitude)

1

2
3
4

5

Strongly Disagree Disagree Neither Agree nor Disagree Agree Strongly Agree 3. People who are important to me think that I should exercise regularly. (Subjective Norm) 1 2

3

4 5

Strongly Disagree Disagree Neither Agree nor Disagree Agree Strongly Agree 4. The people around me participate in exercise. (Subjective Norm)

1 2

3

4 5

Strongly Disagree Disagree Neither Agree nor Disagree Agree Strongly Agree

5. Whether or not I meet my exercise goals is completely up to me. (Perceived Behavioral Control)

1

2

3

4

5

Strongly Disagree Disagree Neither Agree nor Disagree Agree Strongly Agree

6. I plan to be more active each day after coming to this class. (Behavioral Intention)

1

2

3

4

5

Strongly Disagree Disagree Neither Agree nor Disagree Agree Strongly Agree

7. I feel confident that I can incorporate exercise into my weekly routine. (Perceived Behavioral Control)

1

Strongly Disagree
2

Disagree
3

Neither Agree nor Disagree
4

5

Agree Strongly Agree 
8. Chances are that I will meet my written exercise and health goals in the next week. (Behavioral Intention)

1

Strongly Disagree
2

Disagree
3

4

5

\section{Cooking Skills Evaluation Tool}

1. Knowing more tips for grocery shopping will help me choose healthier foods. (Attitude)

1

2

3

4 5

Strongly Disagree Disagree Neither Agree nor Disagree Agree Strongly Agree

2. It is important to me to cook healthy, well-balanced meals. (Attitude)

1

2

3

4 5

Strongly Disagree Disagree Neither Agree nor Disagree Agree Strongly Agree

3. People who are important to me think that I should prepare my own meals. (Subjective Norm)

1

2

3

4

5

Strongly Disagree Disagree Neither Agree nor Disagree Agree Strongly Agree

4. It is expected of me that I know about basic cooking skills. (Subjective Norm)

1

2

3

4

5

Strongly Disagree Disagree Neither Agree nor Disagree Agree Strongly Agree

5. Whether or not I plan and prepare a "home-made" meal is completely up to me. (Perceived Behavioral Control)

1

Strongly Disagree
2

3

Neither Agree nor Disagree
4

5

6. I plan to use this information about at-home cooking after coming to this class. (Behavioral Intention)

1

Strongly Disagree
2

Disagree
3

Neither Agree nor Disagree
4 5 
7. I feel confident that I can plan and prepare a well-balanced meal. (Perceived Behavioral Control)
1
2
3
4 5

Strongly Disagree Disagree Neither Agree nor Disagree Agree Strongly Agree

8. Chances are that I will cook a meal based off of the resources covered today in the next month. (Behavioral Intention)

1

2

3

4 5

Strongly Disagree Disagree Neither Agree nor Disagree Agree Strongly Agree 
Appendix C

Participant Handouts 


\section{NUTRITION LABEL PARTNER ACTIVITY}

Directions: With your partner, use the nutrition label given to you to answer the following questions. When you are finished, compare your answers with the answers of another group and talk about how you got your answers.

1. If you eat one serving size, how many calories will you eat?

2. If you eat the whole container, how many calories will you eat?

3. Does this food contain more fat or carbohydrates?

4. What percentage of the carbohydrates are sugars?

List 2 scenarios where you will read the nutrition label 


\section{NUTRTION LABEL NOTES}

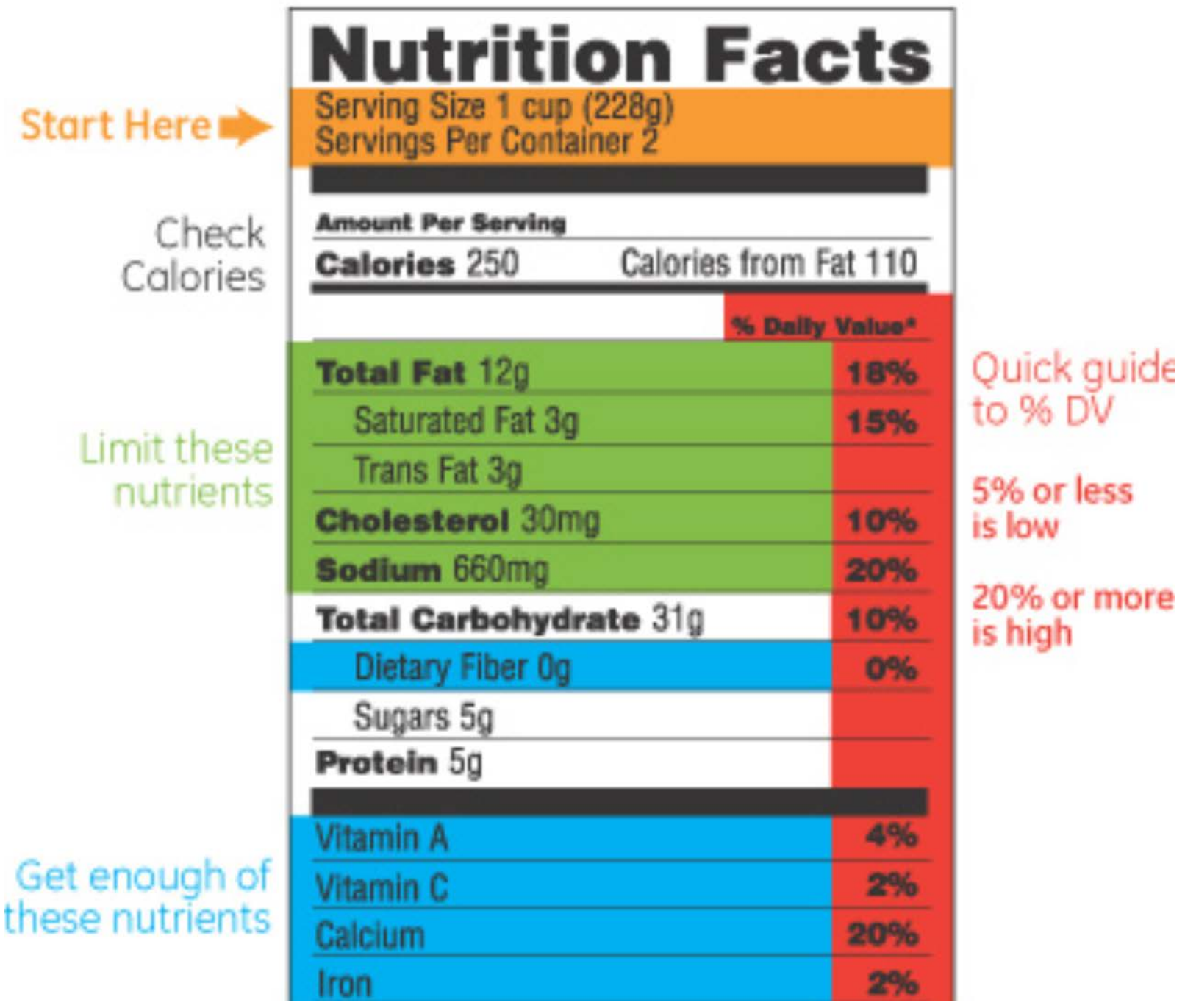




\section{0 tips \\ Nutrition \\ Education Series \\ eating better on a budget}

\section{0 tips to help you stretch your food dollars}

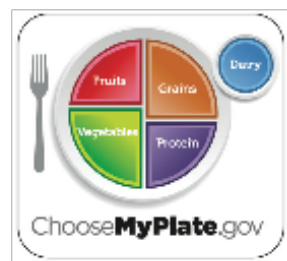

Get the most for your food budget! There are many ways to save money on the foods that you eat. The three main steps are planning before you shop, purchasing the items at the best price, and preparing meals that stretch your food dollars.

plan, plan, plan!

Before you head to the grocery store, plan your meals for the week. Include meals like stews, casseroles, or stir-fries, which "stretch" expensive items into more portions. Check to see what foods you already have and make a list for what you need to buy.

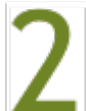

\section{get the best price}

Check the local newspaper, online,

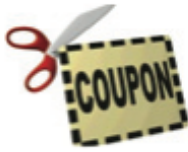

and at the store for sales and coupons. Ask about a loyalty card for extra savings at stores where you shop. Look for specials or sales on meat and seafood-often the most expensive items on your list.

3 compare and contrast

Locate the "Unit Price" on the shelf directly below the product. Use it to compare different brands and different sizes of the same brand to determine which is more economical.

4 buy in bulk

It is almost always cheaper to buy foods in bulk. Smart choices are family packs of chicken, steak, or fish and larger bags of potatoes and frozen vegetables. Before you shop, remember to check if you have enough freezer space.

\section{buy in season}

Buying fruits and vegetables in season can lower the cost and add to the freshness! If you are not going to use them all right away, buy some that still need time to ripen.

\section{convenience costs...} go back to the basics

Convenience foods like frozen dinners, pre-cut vegetables, and instant rice, oatmeal, or grits will cost you more than if you were to make them from scratch. Take the time to prepare your own-and save!

7 easy on your wallet

Certain foods are typically low-cost options all year round. Try beans for a less expensive protein food. For vegetables, buy carrots, greens, or potatoes. As for fruits, apples and bananas are good choices.

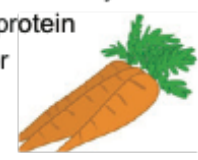

\section{cook once...eat all week!}

Prepare a large batch of favorite recipes on your day off (double or triple the recipe). Freeze in individual containers. Use them throughout the week and you won't have to spend money on take-out meals.

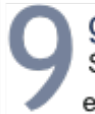

get your creative juices flowing Spice up your leftovers-use them in new ways. For example, try leftover chicken in a stir-fry or over a garden salad, or to make chicken chili. Remember, throwing away food is throwing away your money!

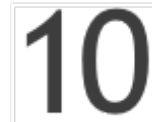
eating out

Restaurants can be expensive. Save money by getting the early bird special, going out for lunch instead of dinner, or looking for "2 for 1" deals. Stick to water instead of ordering other beverages, which add to the bill. 


\section{build a healthy meal 10 tips for healthy meals}

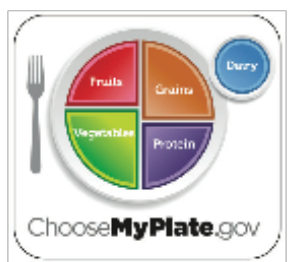

A healthy meal starts with more vegetables and fruits and smaller portions of protein and grains. Think about how you can adjust the portions on your plate to get more of what you need without too many calories. And don't forget dairy-make it the beverage with your meal or add fat-free or low-fat dairy products to your plate.

make half your plate veggies and fruits Vegetables and fruits are full of nutrients and may help to promote good health. Choose red, orange, and darkgreen vegetables such as tomatoes, sweet potatoes, and broccoli.

2 add lean protein Choose protein foods, such as lean beef and pork, or chicken, turkey, beans, or tofu. Twice a week, make seafood the protein on your plate.

\section{2 include whole grains}

Aim to make at least half your grains whole grains. Look for the words " $100 \%$ whole grain" or " $100 \%$ whole wheat" on the food label. Whole grains provide more nutrients, like fiber, than refined grains.

4 don't forget the dairy

Pair your meal with a cup of fat-free or low-fat milk.

They provide the same amount of calcium and other essential nutrients as whole milk, but less fat and calories. Don't drink milk? Try soymilk (soy beverage) as your beverage or include fat-free or low-fat yogurt in your meal.

5 avoid extra fat

Using heavy gravies or sauces will add fat and calories to otherwise healthy choices. For example, steamed broccoli is great, but avoid topping it with cheese sauce. Try other options, like a sprinkling of low-fat parmesan cheese or a squeeze of lemon.

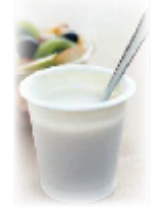

\section{take your time}

Savor your food. Eat slowly, enjoy the taste and textures, and pay attention to how you feel. Be mindful. Eating very quickly may cause you to eat too much.

7 use a smaller plate

Use a smaller plate at meals to help with portion control. That way you can finish your entire plate and feel satisfied without overeating.

\section{take control of your food}

Eat at home more often so you know exactly what you are eating. If you eat out, check and compare the nutrition information. Choose healthier options such as baked instead of fried.

\section{try new foods}

Keep it interesting by picking out new foods you've never tried before, like mango, lentils, or kale. You may find a new favorite! Trade fun and tasty recipes with friends or find them online.

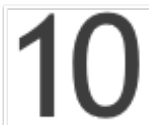
satisfy your sweet tooth in a healthy way Indulge in a naturally sweet dessert dish-fruit! Serve a fresh fruit cocktail or a fruit parfait made with yogurt. For a hot dessert, bake apples and top with cinnamon. 


\section{FACTS ABOUT ORAL CARE}

1. You should brush your teeth 2 times a day for 2 minutes. Once in the morning and once at night. If you can only brush one time each day, it's more important to brush at night. Flossing should be done daily, or as often as possible.

2. When you don't brush your teeth, a film called plaque builds up on your teeth and causes them to be weaker.

3. Don't forget to brush your tongue. Your tongue holds millions of bacteria.

4. When you first begin to brush your teeth more often, it may hurt. The more you brush, the stronger your gums get over time, which means it will be less painful.

5. Rinse your mouth out with water after meals, especially if the meals are high in sugar.

6. Sugar free gum can help remove food particle off of your teeth

7. Smoking increases your risk of getting gum disease, which leads to cancer and tooth loss. It's always a good idea to try to quit!

8. People with diabetes are more likely to get cavities because their body does not fight germs as well.

9. It's very important to go to a dentist or a dental clinic as close to every 6 months as possible.

10. You only get one set of adult teeth, so BRUSH and SMILE!

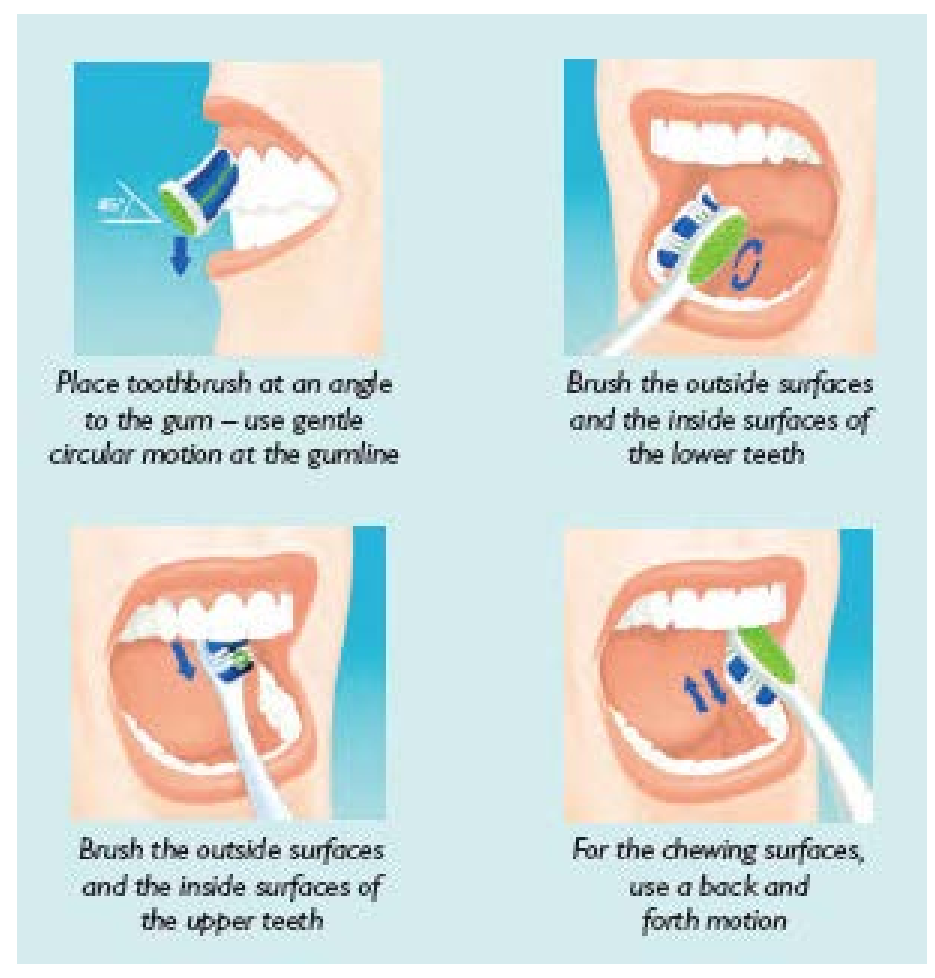




\section{DENTAL CLINICS: FT. WORTH}

\section{Catholic Charities Fort Worth}

Office 817.289.3882

E-mail dental@ccdofw.org

By appointment only. Contact office for scheduling. Eligibility: Potential patients must live within one of the 28 counties served by the Diocese of Fort Worth. Patients qualifying for dental services must have a household income at or below $200 \%$ of the federal poverty guidelines. The dental clinic does not restrict services in regard to religious affiliation, race, ethnicity, gender or disability.

\section{Hope Smile Center}

Call: 817.930.0093

Required: Must be referred by a non-profit organization or be existing client of The Hope Center

Fees: $\$ 35.00$ payment per visit; payment due before each dental treatment; will accept cash, money order and agency checks; no personal checks are accepted; clients who have supplemental dental insurance through Medicare are exempt Documents required: Proof of income; proof of employment search Eligibility: Currently receiving referring agency services; must meet current Federal Poverty Guidelines: must be actively seeking employment through Texas Workforce (or other employment agency) and/or currently enrolled in courses that will increase employment opportunities

Hours: Wed 9:00am - 3:30pm

\section{TCC Dental Clinic}

Call: 817.515.6641

Hours: 8 a.m - 5 p.m.

Cost: $\$ 10$

Services: Teeth cleaning, $x$-rays, sealant, preventative counseling sessions

Location: TCC Northeast Campus- Hurst, TX

Contact Office to schedule an appointment 


\section{FOOT CARE}

1. Wash feet daily with a mild soap and warm water. First test water temperature with hands.

2. Pat feet dry gently, especially between toes.

3. Examine feet daily for cuts, blisters, swelling, and red, tender areas. Do not depend on feeling sores. If you can't check the bottom of your feet, ask someone to look at them.

4. Use lotion on feet to prevent skin from drying and cracking. Do not apply between toes.

5. Cleanse cuts with warm water and mild soap, covering with clean dressing.

6. Tell a doctor about a sore that won't heal as soon as possible.

7. Cut toenails evenly with rounded shape of toes. Do not cut down corners. The best time to trim nails is after a shower or bath.

8. Do not go barefoot. Shake out shoes before putting on.

9. Wear clean, absorbent (cotton or wool) socks.

10. Do not wear tight socks that could decrease blood flow.

11. Do not use hot water bottles or heating pads to warm feet. Wear socks for warmth.

12. Exercise feet daily either by walking or by flexing and extending feet in suspended position. Avoid prolonged sitting, standing, and crossing of legs. 
My Mind, Body, and Soul Goal Sheet

To improve the health of my mind, body and soul...

Today I hope to

Tomorrow I hope to

This week I hope to

This month I hope to

This year I hope to

My Mind, Body, and Soul Goal Sheet

To improve the health of my mind, body and soul...

Today I hope to

Tomorrow I hope to

This week I hope to

This month I hope to

This year I hope to 


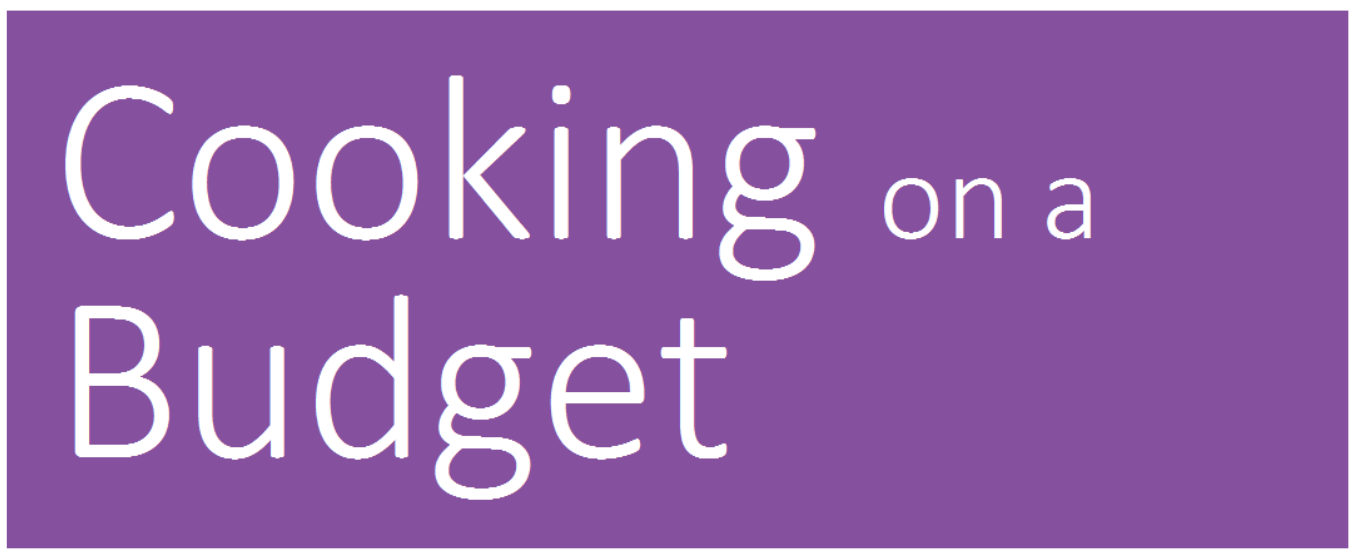

Recipes taken from "Good and Cheap" https://8b852ca0073972f0472b704le2cac21do480P50dl3.googledrive.com/ host/OBXd6wdGBD_2tdUditMOdAWTJ malU/good-and-cheap.pdf

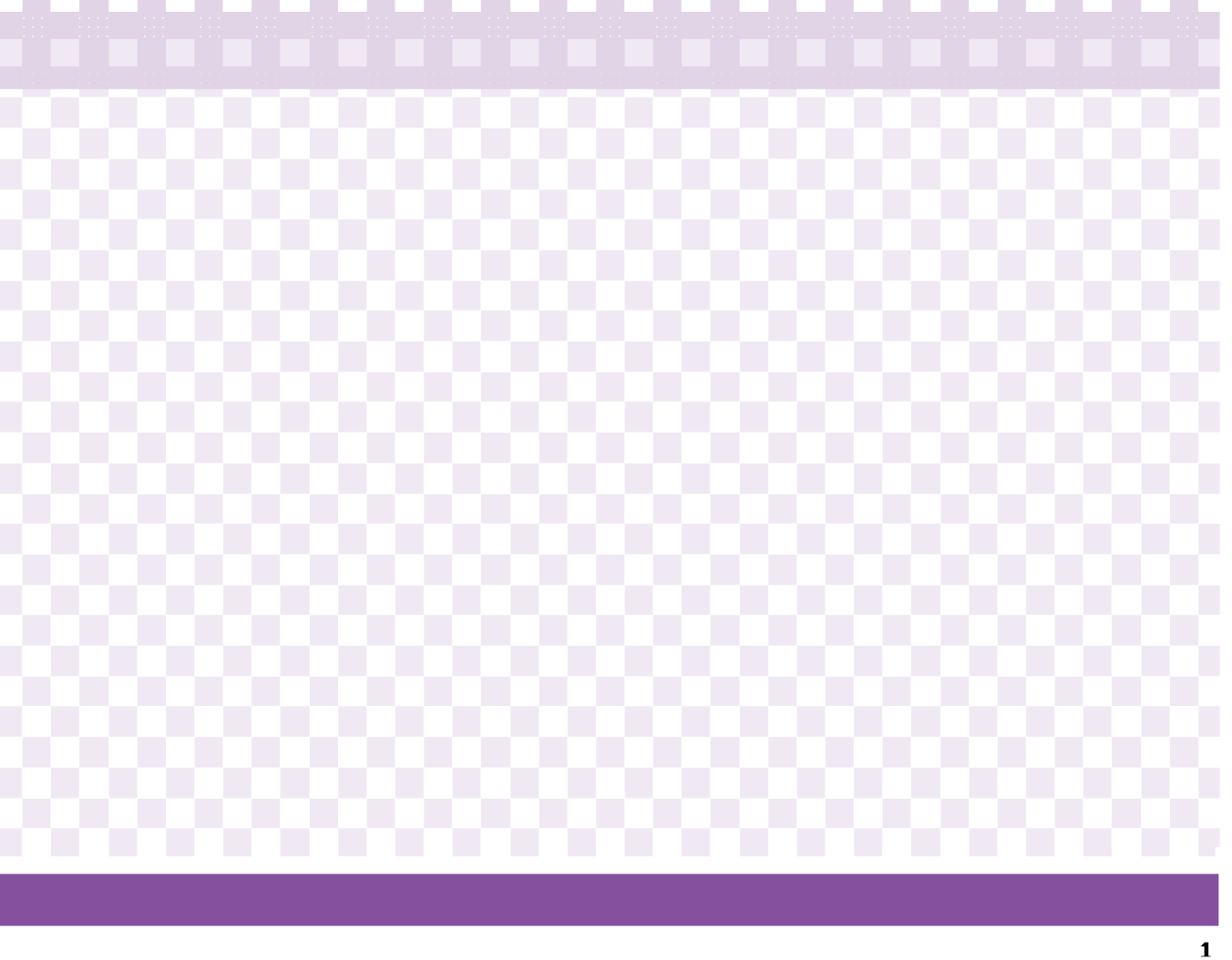


Appendix D

Demographic Survey Information

Demographic Survey

\section{Please write your age:}

2. What race(s) do you most identify with?

American Indian or Alaska Native Asian Black or African American

Native Hawaiian or Pacific Islander White Hispanic/ Latino

\section{Please circle your highest level of education}

No schooling completed Elementary school to $8^{\text {th }}$ grade Some high school

High school graduate, or GED Some college credit

Trade/ technical/vocational training Associate degree Bachelor's degree

\section{What is your marital status?}

Single, never married $\quad$ Married or domestic partnership

Widowed Divorced Separated

5. How long have you been living in a shelter?

\section{Which best describes your job status right now?}

not employed, not looking for a job not employed, looking for a job

disabled, not able to work part-time (up to 20 hours a week)

full-time (up to 40 hours a week) retired 
Table D1

Sample Description Characteristics*

\begin{tabular}{|l|l|}
\hline Characteristic & Number \\
\hline Age & \\
\hline Mean (standard deviation) & $51.8(14.33)$ \\
\hline Range & $26-69$ \\
\hline Ethnicity & \\
\hline African American & $3(50 \%)$ \\
\hline Caucasian & $2(33.3 \%)$ \\
\hline Hispanic/ Latino & $1(16.7 \%)$ \\
\hline Highest Level of Education & \\
\hline High School graduate/ GED & $4(66.7 \%)$ \\
\hline Some College & $1(16.7 \%)$ \\
\hline Bachelor's Degree & $1(16.7 \%)$ \\
\hline Marital Status & \\
\hline Single, Never Married & $3(50 \%)$ \\
\hline Divorced & $2(33.3 \%)$ \\
\hline Widowed & $1(16.7 \%)$ \\
\hline Length of time in Shelter & \\
\hline <1 week & $1(16.7 \%)$ \\
\hline 1 week- 1 month & $1(16.7 \%)$ \\
\hline 1-4 months & $1(16.7 \%)$ \\
\hline 5-8 months & 2 \\
\hline 9-12 months & 1 \\
\hline Employment Status & \\
\hline Not employed, looking for job & 3 \\
\hline Disabled, not able to work & 3 \\
\hline *Lack of demographic data on 4 additional participants
\end{tabular}


Appendix E

Data Analysis Tables

Table E1

Class Objective Completion

\begin{tabular}{|l|l|l|l|l|l|}
\hline & \multicolumn{4}{|c|}{ Construct from the Theory of Planned Behavior } \\
\hline Session Title & Attitude & $\begin{array}{l}\text { Subjective } \\
\text { Norm }\end{array}$ & $\begin{array}{l}\text { Behavioral } \\
\text { Intention }\end{array}$ & $\begin{array}{l}\text { Perceived } \\
\text { Behavioral } \\
\text { Control }\end{array}$ & Knowledge \\
\hline $\begin{array}{l}\text { Health } \\
\text { Literacy }\end{array}$ & Unmet & $\begin{array}{l}\text { Partially } \\
\text { Met }\end{array}$ & Unmet & $\begin{array}{l}\text { Partially } \\
\text { Met }\end{array}$ & Met \\
\hline $\begin{array}{l}\text { Portion } \\
\text { Control and } \\
\text { Easy Food } \\
\text { Swaps }\end{array}$ & Met & $\begin{array}{l}\text { Partially } \\
\text { Met }\end{array}$ & Met & Met & Met \\
\hline $\begin{array}{l}\text { Cooking Skills } \\
\text { Oral and Foot } \\
\text { Care }\end{array}$ & Met & Met & Met & $\begin{array}{l}\text { Partially } \\
\text { Met }\end{array}$ & \\
\hline Exercise & Met & $\begin{array}{l}\text { Partially } \\
\text { Met }\end{array}$ & Met & $\begin{array}{l}\text { Partially } \\
\text { Met }\end{array}$ & Met \\
\hline
\end{tabular}

Table E2

TPB Objective Completion

\begin{tabular}{|l|l|l|l|}
\hline & \multicolumn{3}{|c|}{ Evaluation of Session Objectives } \\
\hline TPB Construct & Met & Unmet & Partially Met \\
\hline Attitude & $80 \%(4 / 5$ & $20 \%(1 / 5$ & $0 \%$ (0/5 Sessions) \\
& Sessions) & Sessions) & \\
\hline $\begin{array}{l}\text { Subjective } \\
\text { Norm }\end{array}$ & $20 \%(1 / 5$ & $20 \%(1 / 5$ & $60 \%(3 / 5$ \\
Sessions) & Sessions) & \\
\hline $\begin{array}{l}\text { Behavioral } \\
\text { Intention }\end{array}$ & $80 \%(4 / 5$ & $20 \%(1 / 5$ & $0 \%(0 / 5$ Sessions) \\
\hline $\begin{array}{l}\text { Perceived } \\
\text { Behavioral } \\
\text { Control }\end{array}$ & Sessions) & Sessions) & \\
\hline Knowledge & Sessions) & $0 \%(0 / 5$ & $60 \%(3 / 5$ \\
& $100 \%(3 / 5$ & Sessions) & Sessions) \\
\hline
\end{tabular}

